ISSN: 0213-2060

DOI: https://doi.org/10.14201/shhme2018361161194

\title{
LAS LIBREAS EN EL SÉQUITO DE FERNANDO EL CATÓLICO: RELACIONES Y REPRESENTACIONES DE LOS PODERES CORTESANOS $^{1}$
}

\author{
The libreas in Ferdinand the Catholic Entourage: Relationships and \\ Representations of the Cortesan Powers
}

\begin{abstract}
Germán GAMERO IGEA
Depto. de Historia Antigua y Medieval. Facultad de Filosofía y Letras. Universidad de Valladolid. Pza del Campus, s/n.E-47011 VALLADOLID. C. e.: german.gamero.igea@hotmail.com
\end{abstract}

Recibido: 2017-02-08

Revisado: 2018-03-13

Aceptado: 2018-05-18

RESUMEN: El presente trabajo presenta una reflexión sobre la donación de libreas en el entorno del Rey Católico. El objetivo que persigue es el de analizar este mecanismo en su contexto cortesano y ponderar su valor en el equilibrio de poderes dentro de la Corte. Para ello se trazará una panorámica general de esta práctica a partir de la documentación conservada. Sin embargo, se incidirá especialmente en un momento muy representativo y bien documentado: la celebración del enlace matrimonial entre el príncipe don Juan y Margarita de Austria. Contextualizando este hecho se demostrará que las prácticas de retribución y libranza de libreas pueden analizarse como un mecanismo de representación del poder regio, pero también del poder cortesano per se.

1 El presente trabajo se encuadra en el Proyecto de Investigación VA058U1475 Islam Medieval en Castilla y León: Realidades, Restos y Recursos Patrimoniales (siglos XIII-XVI), siendo su página web http:// albergueweb.uva.es/islam-medieval-castilla-leon/.

Las principales abreviaturas empleadas en el texto son: $\mathrm{ACA}=$ Archivo de la Corona de Aragón; $\mathrm{RP}=$ Real Patrimonio; $\mathrm{MR}=$ Maestro Racional; AGS = Archivo General del Simancas; $\mathrm{CMC}=$ Contaduría Mayor de Cuentas; EMR = Escribanía Mayor de Rentas; $\mathrm{ARV}=$ Archivo del Reino de Valencia; $\mathrm{RAH}=$ Biblioteca de la Real Academia de la Historia.

Agradezco sinceramente la labor de los revisores de este artículo, cuyas enriquecedoras consideraciones se han incorporado al trabajo en la medida de lo posible. 
Palabras clave: Fernando II de Aragón; Corte; Cortesanos; Representación; Libreas; Príncipe don Juan.

ABSTRACT: This paper reflects about the political use of liveries in Ferdinand the Catholic's Court. The aim of this study is to better understand dress-given in the royal court and its political implications in the court society. To do this, usual and extraordinary moments in the reign of Ferdinand the Catholic will be opposed. Specially it will be stressed the role of liveries on the royal weddings between prince Juan and princess Margarita of Austria in 1497. Facing these two situations, it will be noted how liveries could be understood as a demonstration of royal power in the court but as a courtier mechanism too.

Keywords: Ferdinand II de Aragon; Court; Courtiers; Representation; Liveries; Prince John.

SUMARIO: 0 Introducción. 1 Las relaciones rey-reino en la Corte del último trastámara. Cambios y continuidades. 2 Esquema cromático y representación del poder cortesano. 3 Conclusiones. 4 Apéndice. 5 Referencias bibliográficas.

\section{INTRODUCCIÓN}

El espacio cortesano constituye, hasta su crisis en el siglo XIX, uno de los principales focos políticos, culturales y de sociabilidad de las élites europeas. Su capacidad rectora de esos parámetros sociales ha hecho que la historiografía haya manifestado un gran interés por los más variados aspectos de los séquitos principescos. Tanto es así que, en el estado actual de las investigaciones, resulta complejo establecer una definición estricta de los límites y de la naturaleza del hecho cortesano ${ }^{2}$. Siendo, por tanto, un sujeto de estudio extenso

2 Para una visión de conjunto sobre la bibliografía centrada en el estudio de las cortes y el poder real véase García Vera, María José. «Los estudios sobre la corte y la "sociedad cortesana" a fines de la Edad Media. Un balance historiográfico». Medievalismo, 2000, vol. 10, pp. 207-267; VÁzQuez GesTAL, Pablo. El Espacio del poder. La corte en la historiografía modernista española y europea. Valladolid: Universidad de Valladolid, 2005; Cañas Gálvez, Francisco de Paula. «La evolución política en Castilla durante el siglo Xv: de Juan II a los Reyes Católicos. Perspectiva bibliográfica de la nueva historia política y sus aplicaciones metodológicas».e-Humanista, 2008, vol. 10, pp. 31-50. Para el análisis del entorno cortesano desde una perspectiva europea, al menos deben destacarse algunas obras de referencia como Starkey, David. The English Court: from the War of the Roses to the Civil War. London-New York: Longman, 1987; Asch, Ronald G. y Birke, Adolf M. Princes, Patronage and the Nobility. Oxford: Oxford Universty Press, 1991; Cauchies, Jean Marie. A la cour de Bourgogne. Le duc, son entoruage, son train. Turnhout: Brepols, 1998. Por último, además de la bibliografía que iremos detallando en las siguientes páginas, para los últimos representantes de la dinastía Trastámara pueden destacarse obras como Domínguez Casas, Rafael. Arte y etiqueta de los Reyes Católicos. Artistas, residencias, jardines y bosques. Madrid: Alpuerto, 1993; Martínez López, Francisco. La Casa del príncipe de Asturias (D. Juan, heredero de los Reyes Católicos). Madrid: Dykinson, 2007; GonzÁlez Arce, José Damián. La casa y corte del principe don Juan (1478-1497). Sevilla: Sociedad Española de Estudios Medievales, 2016. 
LAS LIBREAS EN EL SÉQUITO DE FERNANDO EL CATÓLICO: RELACIONES

Y REPRESENTACIONES DE LOS PODERES CORTESANOS

GERMÁN GAMERO IGEA

y ambiguo, conviene determinar, en cada momento, la aproximación metodológica desde la que el investigador se acerca a la Corte. En este trabajo, el análisis de las libreas del Rey Católico se inscribe en la reflexión acerca de la naturaleza de los séquitos curiales.

Así, el debate sobre lo cortesano ha indagado desde sus orígenes sobre el papel de la Corte en el lenguaje y pensamiento político bajomedieval y moderno. Un ejemplo precoz son los debates de la historiografía italiana a este respecto. Como se ha señalado en diferentes ocasiones, en el solar itálico se propusieron en su día algunas cuestiones debatidas después por las diferentes escuelas europeas ${ }^{3}$. Es el caso, por un lado, de la noción de S. Bertelli de la Corte como una colección de cuerpos vendidos al príncipe ${ }^{4}$. A partir de ella diferentes autores han venido valorando los séquitos cortesanos como un centro político esencialmente "principesco», o de poder «descendente». Frente a esta concepción el punto contrastante lo encontramos en la afirmación de A. Stegmann, quien definía nuestro mismo sujeto como la imagen simbólica del Estado5. Podemos usar esta definición como un resumen de la fecunda historiografía que ha buscado en la Corte la expresión de los intereses de la res-publica en cada momento. En ningún caso ambas líneas de investigación deben considerarse opuestas o contradictorias. Al contrario, creemos que la Corte puede entenderse como el lugar donde se conjugan el entendimiento y la rivalidad ${ }^{6}$; en donde la fuerza de los súbditos manifiesta el poder del rey.

En esta reflexión sobre el poder curial se inscribe este trabajo sobre el vestido cortesano, también una expresión de poder ${ }^{7}$. El objetivo, por tanto, se centra en valorar

3 Martínez Millán, José. «La sustitución del "sistema cortesano" por el paradigma del "Estado nacional” en las investigaciones históricas”. Libros de la Corte, 2009, vol. 1, pp. 4-17; Rivero RodríGuez, Manuel. "Court Studies in the Spanish World». En Fantoni, Marcello (ed.). The court in Europe. Roma: Bulzoni, 2012, pp. 123-147.

4 Bertelli, Sergio. «Il conceto di Corte». En Margolin, Jean-Claude; Bigalli, Davide; Tenenti, Alberto; Ingenio, Alfonso y Vassoli, Cesare (coords.). Ragione e civilitas. Figure del vivere associato nella cultura del' 500 europeo. Milano: Franco Angeli, 1986, p. 143.

5 Stegmann, André. «La Corte. Saggio di definizione teorica». En Romani, Marzio A. (ed.). Le corti farnesiane di Parma e Piacenza (1545-1622). Roma: Biblioteca del Cinquecento, 1978, Vol. I, pp. XXI-XXVI.

6 SuÁrez Fernández, Luis. Nobleza y monarquia: entendimiento y rivalidad. El proceso de construcción de la Corona española. Madrid: La Esfera, 2003.

7 Reflexiones como la de José Damián González Arce, por las que debemos entender el vestido como «un sistema normativo organizado por la colectividad, en el que los elementos no tienen valor por sí mismos, sino que lo tienen en tanto que están ligados a un conjunto de reglas comunitarias», nos han ayudado en el planteamiento de estas cuestiones. Vid. González Arce, José Damián. «Los colores de la corte del príncipe Juan (1478-1497), heredero de los Reyes Católicos. Aspectos políticos, estéticos y económicos». Espacio, Tiempo y Forma. Serie III. Historia Medieval, 2013, vol. 26, pp. 185-208. Para el caso de los Reyes Católicos, el uso propagandístico de la imagen regia (y en particular del vestido) por parte de los soberanos, y especialmente de Isabel I, resulta indudable. Estudios que así lo han puesto de manifiesto son: Fernández de Córdova Miralles, Álvaro. La Corte de Isabel I. Ritos y ceremonias de una reina (1464-1504). Madrid: Dykinson, 2002; Carrasco Manchado, Ana Isabel. Isabel I de Castilla y la sombra de la ilegitimidad. Propaganda y representación en el conflicto sucesorio (1474-1482). Madrid: Sílex, 2006; Martínez Martínez, María. «La creación de una moda propia en la España de los Reyes Católicos». Aragón en la Edad Media, 2006, vol. 19, pp. 343-380; Zalama RodrígueZ, Miguel Ángel. «Oro, perlas, brocados... La ostentación en el vestir en la corte de los Reyes Católicos». 
LAS LIBREAS EN EL SÉQUITO DE FERNANDO EL CATÓLICO: RELACIONES Y REPRESENTACIONES DE LOS PODERES CORTESANOS GERMÁN GAMERO IGEA

la iniciativa del reparto de libreas como parte de la relación entre el rey y las élites de sus reinos en el seno de la Corte. Por ello, trataremos este aspecto esencialmente como un pretexto para clarificar una situación más amplia. Ello ha condicionado la menor atención que mostraremos a otros aspectos del vestir bajomedieval como su simbología, el color o la moda. Sin duda se trata de elementos esenciales, pero, ante la falta de espacio en un trabajo de estas características, nos remitimos a los múltiples trabajos especializados sobre el tema ${ }^{8}$. Por el contrario, nuestro interés residirá en delimitar si debemos considerar la donación de libreas tan solo como un ejemplo de liberalidad (esto es, como una virtud regia) o si también podemos observar en esta práctica un ejercicio de poder. Explorando especialmente esta segunda opción, nos preguntaremos también el papel que el rey y las élites cortesanas tuvieron en este juego.

Para tratar de responder a estas preguntas nuestro estudio se desarrollará desde dos perspectivas. La primera de ellas se centrará en la práctica cotidiana del reparto de libreas a lo largo del gobierno del Rey Católico. Tras ello nos centraremos en un análisis detallado

Revista de Estudios Colombinos, 2012, vol. 8, pp. 13-22; Pascual Molina, Jesús Félix. «Magnificencia y poder en los festejos de la primera mitad del siglo XVI». En Rodríguez Moya, Inmaculada y Mínguez Cornelles, Víctor. Visiones de un imperio en fiesta. Madrid: Fundación Carlos de Amberes, 2016, pp. 121-144; Descalzo Lorenzo, Amalia. «Vestirse a la moda en la España Moderna». Vinculos de Historia, 2017, vol. 6, pp. 89-204; García Marsilla, Juan Vicente. «La moda no es capricho. Mensajes y funciones del vestido en la Edad Media». Vinculos de Historia, 2017, vol. 6, pp. 71-88. Una visión de la siempre influyente Corte de Borgoña puede verse en Jolivet, Sophie. «Le phénomène de mode à la cour de Bourgogne sous Philippe le Bon: l'exemple des robes de 1430 à 1442». Revue du Nord, 2006, vol. 365, n. ${ }^{\circ}$ 2, pp. 331-345; Bartholeyns, Gil. "Gouverner par le vêtement. Naissance d'une obsession politique». En Genet, Jean-Philippe y Mineo, E. Igor (dirs.). Marquer la prééminence sociale. Paris-Roma: Publications de la Sorbonne-École Française de Rome, 2014, pp. 215-232. Resultan igualmente interesantes las múltiples referencias literarias a las que hace mención el trabajo de FerNáNDeZ de Córdova Miralles, Álvaro. «Los símbolos del poder real». En Bartolomé, Alberto y HerNANDo, Carlos José. Los Reyes Católicos y Granada. Granada: Sociedad Estatal de Conmemoraciones Culturales, 2005.

8 Bernis, Carmen. Trajes y modas en la España de los Reyes Católicos. Madrid: Consejo Superior de Investigaciones Científicas, 1978-1979; Castillo Ocaña, Argente del. "Carmen, el vestido en la sociedad castellana bajomedieval». En García Wiedemann, Emilio J. y Montoya Ramírez, M. ${ }^{a}$ Isabel (eds.). Moda y sociedad. Estudios sobre educación, lenguaje e historia del vestido. Granada: Universidad de Granada, 1998, pp. 69-102; González Marrero, María del Cristo. La casa de Isabel la Católica. Espacios domésticos y vida cotidiana. Ávila: Institución Gran Duque de Alba, 2005; ÍDem. «Un vestido para cada ocasión: la indumentaria de la realeza bajomedieval como instrumento para la afirmación, la imitación y el boato. El ejemplo de Isabel I de Castilla». Cuadernos del Cemyr, 2014, vol. 22, pp. 155194; Osés UrRicelqui, Mercedes. Poder, simbología y representación en la Baja Edad Media. El ajuar en la corte de Carlos III de Navarra (1387-1425). Tesis doctoral inédita defendida en la Universidad Pública de Navarra en 2015 (disponible en https://academica-e.unavarra.es/xmlui/handle/2454/18004). Relativamente recientes y sobresalientes en cuanto a sus consideraciones en torno al color son las obras de Quondam, Amadeo. Tutti i colori del nero. Moda e cultura nell'Italia del Cinquecento. Roma: Colla Editore, 2010; Paulicelli, Eugenia. Writing Fashion in Early Modern Italy. London: Routledge, 2016. Por último, resulta imprescindible mencionar cualquiera de las obras de Michel Pastoureau, entre las que por razones de espacio tan solo destacaremos Pastoureau, Michel. Diccionario de los colores. Barcelona: Paidós Ibérica, 2009. 
LAS LIBREAS EN EL SÉQUITO DE FERNANDO EL CATÓLICO: RELACIONES

Y REPRESENTACIONES DE LOS PODERES CORTESANOS

GERMÁN GAMERO IGEA

de un momento concreto: la boda del príncipe Juan y sus celebraciones burgalesas?. Así, entre los registros conservados para el reinado de Fernando II de Aragón este es sin duda el acontecimiento que mayores gastos refleja. Esto no quiere decir que no se produjesen otros hitos celebrativos del periodo, ni que el vestido participase en menor medida en este proceso. Ejemplo claro de esta realidad es el de las bodas de la infanta Isabel en Sevilla, por ejemplo ${ }^{10}$. Sin embargo, por motivos de conservación documental no resulta sencillo ofrecer una visión comparativa más allá de la propia evolución interna del séquito regio ${ }^{11}$.

\section{Las relaciones rey-reino en la Corte del último trastámara. Cambios y CONTINUIDADES}

La Corte del Rey Católico es un sujeto de estudio hasta el momento poco analizado. Esta circunstancia se debe en parte a la dispersión documental y en parte a la propia situación del reinado, a medio camino entre Aragón y Castilla, y entre el Medievo y la Modernidad ${ }^{12}$. Todo ello ha hecho que los trabajos relacionados con

9 Afirma Zurita en su tercer libro de las Empresas y Ligas de Italia, título segundo: y este parentesco de la casa de Austria fue tan envidiado, y obligado con los dos casamientos, el rey, y reina acordaron de hacer con tanto gasto, y aparato las fiestas del matrimonio de su hijo, cuanto se podía esperar de su grandeza. Disponible en http://ifc.dpz.es/publicaciones/ver/id/2423 (consultado el 23/05/2015).

${ }_{10}$ Así por ejemplo sabemos que para la boda de la infanta Isabel cien continos fueron arreados de vestiduras brocadas e chapadas e bordadas de oro y plata, e ningún caballero ni fijodalgo ovo en aquellas fiestas que paresciese vestido salvo de paño de oro e de seda. Noticia recogida en Pulgar, Hernando del. Crónica de los señores Reyes Católicos Don Fernando y Doña Isabel de Castilla y de Aragón. Valladolid: Junta de Castilla y León, 2011 [reimpresión de la edición de Valencia, Imprenta de Benito de Monfor, 1780], p. 368.

11 Con diferentes connotaciones, podemos documentar otros casos de libreas generalizadas en esta cronología, como las repartidas en los séquitos de sus hijas. El matrimonio se vuelve a convertir en el momento idóneo para la generalización de estas libranzas. Tal es el caso de los esponsales de la archiduquesa Juana (AGS, CMC, Leg. 128, s/f.; vid. Ladero Quesada, Miguel Ángel. «Actividades de Luis de Santángel en la corte de Castilla». Historia. Instituciones. Documentos, 1992, vol. 19, pp. 231-252) y los de la princesa de Gales (Andrés Díaz, Rosana de. El último decenio del reinado de Isabel I a través de la tesorería de Alonso de Morales. Valladolid: Universidad de Valladolid, 2004, pp. 581-584 y 681-684). Los oficiales de Juana, ya como princesa, recibirían también una librea completa como se observa en Ibidem, pp. 885-889. Para otras celebraciones, como las entradas reales, véase Andrés DíAz, Rosana de. «Las entradas reales castellanas en los siglos XIV y XV, según las crónicas de la época». En la España Medieval, 1984, vol. 4, pp. 47-62; y RAUfAST CHICO, Miguel. «E vingueren los officis e confraries ab llurs entremeses e balls: una aproximación al estamento artesanal en la Barcelona bajomedieval, a partir del estudio de las ceremonias de entrada real». Anuario de Estudios Medievales, 2006, vol. 36, n.o 2, pp. 651-686.

12 Si bien la bibliografía a este respecto resulta inabarcable, sobre la política del reinado y el protagonismo de algunos de sus cortesanos son de referencia obligada estudios como Vicens VIVES, Jaume. Ferran II y la ciutat de Barcelona, 1479-1516. Barcelona: Universidad de Barcelona, 1936; SeSMA Muñoz, Ángel. Fernando de Aragón: Hispanorum Rex. Zaragoza: Gobierno de Aragón, 1992; SARASA SÁnchez, Esteban (coord.). Fernando II de Aragón, el Rey Católico. Zaragoza: Institución Fernando el Católico, 1996; Suárez Fernández, Luis. Fernando el Católico. Barcelona: Ariel, 2004; Belenguer Cebrià, Ernest. Fernando el Católico y la ciudad de Valencia. Valencia: Servicio de Publicaciones de la Universidad de Valencia, 2012. 
LAS LIBREAS EN EL SÉQUITO DE FERNANDO EL CATÓLICO: RELACIONES Y REPRESENTACIONES DE LOS PODERES CORTESANOS GERMÁN GAMERO IGEA

su Corte sean más bien escasos ${ }^{13}$. Excepciones a este respecto son la preocupación de Jaume Vicens Vives por los más diversos aspectos de la vida de Fernando II $^{14}$ y el interés despertado por la Cancillería de los reyes de Aragón ${ }^{15}$. Por este motivo debemos retomar algunas ideas generales sobre este séquito, ya defendidas en otros trabajos, pero que nos permiten establecer algunas coordenadas básicas para su comprensión y análisis ${ }^{16}$. Uno de ellos es la relevancia de las Ordinacions de Pedro IV como modelo cortesano ideal todavía para los soberanos trastámaras. Así, aunque no sea el objetivo principal de este estudio, la primera consideración con la que deberíamos acercarnos a este entorno curial se basa en el respeto que se tuvo a este texto en época del Rey Católico, mucho más acusado de lo que el paso del tiempo podría hacernos suponer. Fruto de este respeto es la división en cuatro grupos (que a lo largo del texto denominaremos «departamentos» siguiendo la terminología francesa ${ }^{17}$ ): el de la Casa, la Cámara, la Cancillería y el Maestre Racional. Cada uno de ellos poseía un oficial al mando de sus subordinados, mientras que el Maestre Racional seguía funcionando como figura fiscalizadora de todos ellos. Sin embargo, las Ordinacions deben ser entendidas, más que como una planta administrativa rígida, como unas directrices generales tendentes al buen gobierno, al equilibrio de los poderes cortesanos. Tomadas como un referente

13 Deben destacarse las referencias a la Corte del infante don Fernando recogidas en Gual CAmarena, Miguel. "Servidores del infante don Fernando (1458-1462)». En Estudios de Edad Media de la Corona de Aragón. Zaragoza: Consejo Superior de Investigaciones Científicas, 1956, pp. $267-280$. Más recientemente pueden destacarse algunos trabajos que analizan la Corte de los Reyes Católicos, y de cuyas conclusiones es deudor este trabajo. Vid. Ladero Quesada, Miguel Ángel. "La casa real en la Baja Edad Media». Historia. Instituciones. Documentos, 1998, vol. 25, pp. 327-350 y VALDEÓN Baruque, Julio. «La corte en Castilla en la época trastámara». Aragón en la Edad Media, 1999, vol. 14-15, pp. 1597-1608. En especial, merecen también una atención particular los estudios sobre el entorno musical del rey recogidos en Knighton, Tess. Música y músicos en la corte de Fernando el Católico. Zaragoza: Institución Fernando el Católico, 2001; así como la evolución de su séquito desde la muerte del príncipe Juan y durante las regencias castellanas: Martínez Millán, José (coord.). La Corte de Carlos V. Madrid: Sociedad Estatal para la Conmemoración de los Centenarios de Felipe II y Carlos V, 2000.

14 Vicens Vives, Jaume. Historia crítica de la vida y reinado de Fernando II de Aragón. Zaragoza: Institución Fernando el Católico, 2007 [Primera versión de 1962].

15 Sevillano Colom, Francisco. «La Cancillería de Fernando el Católico». En Actas del V Congreso de Historia de la Corona de Aragón. Zaragoza: Institución Fernando el Católico, 1955, pp. $217-$ 353; Baltar Rodríguez, Juan Francisco. El protonotario de Aragón, 1472-1707: la Cancillería aragonesa en la Edad Moderna. Zaragoza: El Justicia de Aragón, 2001.

16 Gamero IgeA, Germán. «El modelo administrativo de la Corte de Fernando el Católico. Cambios y permanencias en la gestión cortesana de la Corona de Aragón». e-Spania, 2015, vol. 20; ÍDEM. «Los lazos familiares en la articulación cortesana de Fernando el Católico». En GARCía HerNÁndez, Máximo (ed.). Familia, cultura material y formas de poder en la España Moderna. Madrid: FEHM, 2016, pp. 33-42; ÍDEM. «Ordenar la Corte y gobernar los territorios. Dinámicas y estructuras de poder en el entorno de Fernando el Católico». En Nieva, Guillermo; González, Rubén y Navarro, Andrea M. (coords.). El principe, la corte y sus reinos. Tucumán: Universidad Nacional de Tucumán, 2016, pp. 139-166.

17 Gonzalez, Élisabeth. Un Prince en son Hôtel. Les serviteurs des ducs d'Orléans au XV siècle. Paris: Publications de la Sorbonne, 2004. 
LAS LIBREAS EN EL SÉQUITO DE FERNANDO EL CATÓLICO: RELACIONES

Y REPRESENTACIONES DE LOS PODERES CORTESANOS

GERMÁN GAMERO IGEA

y una autoridad, el orden cortesano debía ir modificándose conforme impusieran las circunstancias ${ }^{18}$.

Por lo que respecta a las condiciones del servicio, y especialmente a la percepción de vestuarios, la dinámica cortesana sigue un esquema semejante que oscila entre la tradición y la innovación. Es sabido que los cortesanos de la Corona de Aragón tenían derecho a un vestuario como otro concepto suplementario al de su quitación (como pudiera ser la ración $)^{19}$. Como una percepción reglada, los reyes aragoneses desde Pedro IV fueron estableciendo el monto que debían recibir anualmente sus oficiales en función de su rango ${ }^{20}$. Esto es lo que, en nuestra opinión, deberíamos considerar como vestuarios ordinarios. Frente a ellos, el monarca podía conceder un sinfín de vestuarios extraordinarios por los más diversos motivos. Dada la casuística, podríamos diferenciarlos entre regulares o esporádicos, pero resulta importante destacar que se trataba siempre de una merced graciosa ${ }^{21}$. La segunda tipología, propia de nuestro caso de estudio, se refiere a la dotación de libreas con motivo de los más variados acontecimientos. En cuanto a las libreas regulares, más interesantes para este apartado del trabajo, se podrían definir como vestuarios concedidos con motivo de diferentes fiestas del calendario. Por ejemplo, para el caso fernandino podemos destacar las donaciones de telas a los Monteros de Espinosa en San Juan y en Navidad ${ }^{22}$. También resulta interesante considerar la celebración de la

18 Sobre la concreción práctica del esquema de las Ordinacions véase BeAuchamp, Alexandra. «Ordonnances et réformes de l'Hôtel Royal au début du règne de Pierre IV d'Aragón». Anuario de Estudios Medievales, 2009, vol. 39, n. ${ }^{\circ}$ 2, pp. 555-573; ÍDEM. «La composition de la Casa i Cort du roi d'Aragon. Normes et pratiques au début du règne de Pierre le Cérémonieux». Erasmo. Revista de Historia Bajomedieval y Moderna, 2014, vol. 1, pp. 21-42; y sobre su difusión, Palacios Martín, Bonifacio. «Sobre la redacción y difusión de las Ordinacions de Pedro IV de Aragón y sus primeros códices». Anuario de Estudios Medievales, 1995, vol. 25, n. ${ }^{o}$ 2, pp. 659-682. Para la visión de la Corte de los últimos trastámaras de Aragón puede verse MuÑoz GómEz, Víctor. «Una aproximación a la presencia castellana en el gobierno de la Corona de Aragón durante el reinado de Fernando I». En FaLcón, Isabel (coord.). XIX Congreso de Historia de la Corona de Aragón. Zaragoza: Obra Social de Ibercaja, 2013, pp. 548-559; Sainz Serrano, Jorge. «Acompagner et servir le prince. Structure et fonctionament de la Maison royale d'Alphonse V D'Aragon». En Beauchamp, Alexandra (coord.). Les entourages princiers à la fin du Moyen Âge. Madrid: Casa de Velázquez, 2013, pp. 131-150; ChIlÀ, Roxane. Une cour à l'épreuve de la conquête: la société curiale et Naples, capitale d'Alphonse le Magnanime (1416-1458). Tesis doctoral inédita defendida en la Université Paul Valéry-Montpellier III en el año 2014 (disponible en https://tel.archives-ouvertes.fr/tel-01144965/); y GAMERo IGEA, Germán. «Epílogo de un reinado y desmembramiento de una Corte: servidores de Juan II de Aragón a su muerte». Medievalismo, 2016, vol. 26, pp. 109-133.

19 Gimeno, Francisco M.; Gozalbo, Daniel y Trenchs, Josep (eds.). Ordinacions de la Casa i Cort de Pere el Ceremoniós. València: Publicacions de la Universitat de València, 2009.

20 Sobre la adecuación de dichas percepciones a lo largo del tiempo existe abundante información en ARV, Real Cancillería, Leg. 622. Legajo en el que se reúnen las conocidas como Adicions.

21 Narbona Cárceles, María. La corte de Carlos III el Noble, rey de Navarra: espacio doméstico y escenario del poder, 1376-1415. Pamplona: Eunsa, 2006, pp. 144-145.

22 En algunos años, como por ejemplo en 1505, estas donaciones se hacen en dinero. No obstante, en las partidas de gasto se hace expresa referencia a las telas que se han de comprar y a las prendas que se han de confeccionar (vid. ACA, RP, MR, Vol. 876, fol. 258r). Esta práctica debía ser también frecuente en Castilla, en cuyos libros de tesorería nos encontramos el pago de libreas en Navidad a estos 
LAS LIBREAS EN EL SÉQUITO DE FERNANDO EL CATÓLICO: RELACIONES Y REPRESENTACIONES DE LOS PODERES CORTESANOS GERMÁN GAMERO IGEA

Virgen de la Candelaria. En esta fecha el soberano donaba anualmente una ropa de estado a los marqueses de Cádiz en remuneración y conmemoración de los servicios prestados en las campañas granadinas ${ }^{23}$. Sin embargo, esta dadivosidad del Rey Católico no es más que un ejemplo dentro de una práctica generalizada en el contexto europeo ${ }^{24}$.

Cada una de estas prácticas, conforme a su contexto, tuvo su significado propio, que afectaba a la valoración de la Corte y de los cortesanos. Así, entre las modificaciones detectables en nuestra cronología nos podemos encontrar algunas prácticas que influyeron directamente en la consideración de los oficiales al modificar sus vestuarios ordinarios, esto es, a su percepción salarial. Así, sabemos que al menos desde el reinado de Juan II el vestuario-quitación había desaparecido para la mayoría de los departamentos cortesanos. Esta percepción salarial se había restringido a la Cancillería y al Maestre Racional (esto es, a la Tesorería General y a la Escribanía de Ración incluidas) ${ }^{25}$. No creemos que esta modificación fuese casual, si tenemos en cuentra que hace referencia a las oficinas más conectadas con la administración de los reinos frente a los departamentos más vinculados con la dimensión personal del rey, mucho más vinculados a la gracia regia.

Por lo que respecta a la Corte de su hijo, Fernando II, el estado de conservación nos obliga a ser cautos, al haberse perdido los registros de la Tesorería. Para acercarnos a esta problemática dependemos de la información contenida en los registros de quitaciones y los denominados albalaes ordinarios y extraordinarios. No obstante, ambas tipologías apuntan a la mecánica mencionada para el reinado anterior. Solo los miembros de las oficinas administrativas (y no todos) reciben parte de su salario en concepto de vestuario ${ }^{26}$. Ya este cambio podría resultar suficientemente llamativo por la dimensión política y simbólica que

oficiales. Un ejemplo lo podemos encontrar en Torre, Antonio de la y Torre, Engracia Alsina de la. Cuentas de Gonzalo de Baeza tesorero de Isabel la Católica. Madrid: Consejo Superior de Investigaciones Científicas, 1955-1956, vol. 2, p. 526.

${ }^{23}$ Una copia de este privilegio se encuentra en RAH, Colección Salazar y Castro, Vol. B-3, fol. $358 \mathrm{v}$.

24 La historiografía ha remarcado suficientemente el capítulo de Fernández de Oviedo en el que se describe la educación del príncipe por parte de la reina a este respecto. Nos remitimos tan solo al mencionado pasaje, por falta de espacio: Fernández de Oviedo, Alonso. Libro de la Cámara Real del principe don Juan, oficios de su casa y servicio ordinario (Santiago Fabregat Barrios, ed.). València: Universitat de València, 2006, pp. 111-114. De la misma manera, como señala María Concepción Quintanilla Raso, este mismo tipo de regalos puede encontrarse en el reinado de Juan II; vid. QuintaniLLA Raso, M. ${ }^{a}$ Concepción. «La nobleza». En Nieto Soria, José Manuel. Origenes de la monarquía hispánica: propaganda y legitimación ca.1400-1520. Madrid: Dykinson, 1999, pp. 63-104, en concreto p. 95.

25 Hemos tomado como referencia el análisis de las noticias contenidas en ARV, Tesorería Real, Vol. 831.

26 Las tipologías de oficiales que claramente reciben este tipo de retribución son las relacionadas con la gestión económica (escribanos de la Escribanía de Ración y Tesorería) y los secretarios. Ejemplos de esta dinámica son: Jaume Monfort, escribano de la Tesorería, que recibe su vestuario en 1478 (ACA, RP, MR, Vol. 838, fol. 11r); Juan Climent, escribano de la Escribanía de Ración, a quien encontramos recibiendo vestuarios desde 1494 (ACA, RP, MR, Vol. 840, fol. 38r); o el secretario Gaspar de Arinyo para el que tenemos noticias de sus vestuarios desde 1481 (ACA, RP, MR, Vol. 838, fol. 152r) Sin embargo, los ejemplos son muy numerosos, requiriendo una descripción y análisis alejado de las dimensiones de este trabajo. 
LAS LIBREAS EN EL SÉQUITO DE FERNANDO EL CATÓLICO: RELACIONES

Y REPRESENTACIONES DE LOS PODERES CORTESANOS

GERMÁN GAMERO IGEA

conllevaba. Pero podría destacarse un nuevo rasgo, más revelador si cabe, en lo que respecta a la modificación de los vestuarios. Así pues, si nos alejamos de los oficiales más administrativos, cuya situación ya hemos destacado, la inmensa mayoría de albalaes en estos reinados se refiere a pagos en especie: telas y, más raramente, ropas ya confeccionadas ${ }^{27}$. No se trata de asignaciones económicas como ocurría en las libreas ordinarias. Por supuesto esta afirmación puede matizarse. Podemos encontrar partidas que muestran la donación de dinero en concepto de vestuario. Sin embargo, estos asientos contables no son sistemáticos en el tiempo y suelen hacer referencia a capellanes o cortesanos con características muy específicas. Además, en ambos casos se observa una consideración personal más que al cargo en $s^{228}$.

Por lo que respecta a los pagos de libreas en especie, aquí sí encontramos una referencia directa al oficio. La inmensa mayoría de estas partidas se vinculan con los oficiales relacionados con la caza (cazadores, monteros y mozos de lebreles) y con la caballeriza (esto es, mozos de espuelas y hombres de pie ${ }^{29}$. La selección de los cortesanos que recibirían estos textiles parece justificada. En ambos casos sus actividades implicaban, a partes iguales, una degradación considerable de su vestuario en el ejercicio de sus tareas, y una importante carga en la representación de la monarquía. Si resulta ineludible la cuestión del deterioro de las prendas, es más interesante para nuestros objetivos la relación con la representación mayestática. En primer lugar, parece evidente la diferente consideración de los vestuarios como salario, destinada a valorar la figura de los gestores del Estado, y aquella de tipo material, que se apropia de los cuerpos de algunos oficiales regios. La selección de estos servidores tampoco parece casual. La caza y la caballeriza resultan dos ambientes claramente vinculados con el ideal caballeresco, tan en boga en nuestra cronología. Así, la caza supone una recreación de la actividad bélica del soberano ${ }^{30}$. Mientras, la caballeriza personifica la imagen icónica y romántica del noble guerrero al final del Medievo $^{31}$. En este sentido, tampoco parece casual que los dos cuerpos militares creados para la Corte del Rey Católico recibiesen indicaciones de vestuario. Nos referimos al cuerpo de los cien alabarderos, surgido durante su viaje a Nápoles ${ }^{32}$, y el de los gentileshombres, que emerge inmediatamente antes de la conquista de Navarra ${ }^{33}$. De ellos

27 No es infrecuente encontrarnos con mercedes de calzas para los mozos de espuela o de la caballeriza, seguramente por el propio desgaste de las prendas. Uno de los múltiples ejemplos puede verse en ACA, RP, MR, Vol. 877, fol. 64r.

${ }_{28}$ Los ejemplos son muy numerosos; véase ACA, RP, MR, Vol. 876, fols. 12r, 17r, 19r, 120r, $124 \mathrm{v}$, y un largo etcétera.

29 Resulta igual de frecuente el pago de libreas a estos oficiales, o semejantes, en la Corte de la Reina Católica, como se desprende de las cuentas de la tesorería. Torre y Torre, Cuentas de Gonzalo de Baeza, Vol 2, pp. 278, 206, 480, 499, 524, 526 y 607.

30 Paravicini Bagliani, Agostino. La chasse au Moyen Âge: société, traités, symboles. Firenze: SISMEL-Edizioni del Galluzzo, 2000.

31 Huizinga, Johan. El otoño de la Edad Media. Madrid: Alianza Editorial, 2005 [de la primera edición en español publicado en Revista de Occidente, en 1930].

32 Para conocer los vestidos confeccionados para «los cien alabarderos del rey» se conserva la nómina del 12 de enero de 1506 en la que se hace mención expresa a los «sayones franceses» que debían portar, entre otras vestiduras, véase ACA, RP, MR, Vol. 877, fol. 86r.

33 En cuanto a las peculiaridades del vestuario que se determinan en la creación del cuerpo de gentileshombres, véase ACA, RP, MR, Vol. 940, fols. 6 y ss. 
cabe destacar que, si bien al primero de los grupos se le donaría su vestuario cada año, al segundo se entiende que lo deberían aportar ellos mismos. La diferencia es sustancial, propia de la distinta valoración entre los primeros (a modo de guardas regios) y los segundos (un cuerpo de élite política y militar).

Todas estas situaciones muestran cómo había ocurrido un cambio sustancial durante los años centrales del siglo Xv en la Corte de los soberanos aragoneses. Los vestuarios habían dejado de ser algo neutro, cuya materialización quedaba a la libre disposición del cortesano. Por el contrario, les encontramos mucho más controlados por el poder, y en especial contribuyendo a la representación caballeresca del rey cuando estos se concedían en especie. Sin embargo, la participación en esta dinámica es minoritaria. En el tiempo ordinario se manifiesta en un grupo de cortesanos muy reducido y, además, relegado de los mecanismos de la política cortesana. Si tan significativas son las presencias, no lo son menos las ausencias de estos comportamientos en otros oficiales especialmente representativos para el poder curial como los relacionados con la Cámara o con la mesa regia. Incluso, el mantenimiento de los vestuarios ordinarios (esto es, a modo de percepción salarial) en el caso de los gestores políticos y económicos nos habla, con otro vocabulario, de esta misma fuerza en el seno del entorno regio. No obstante, para poder analizar esta dinámica en su totalidad debemos preguntarnos qué ocurriría en los momentos de especial atención y despliegue simbólico, como las fiestas. Es aquí donde parece pertinente el análisis de la situación esporádica en el reparto de libreas.

\section{ESQUEMA CROMÁTICO Y REPRESENTACIÓN DEL PODER CORTESANO}

A lo largo de las páginas precedentes hemos observado cómo la donación de libreas y vestuarios se había reducido (y reconducido) en el tiempo ordinario de la monarquía. Sin embargo, en el mutable escenario cortesano todo matiz puede cambiar el significado de la faz cortesana, y sin duda las celebraciones festivas suponían una oportunidad simbólica y semiótica para introducir los más diversos significados ${ }^{34}$. El azar, y en cualquier caso la archivística, nos han legado algunas noticias relacionadas con las celebraciones dinásticas del Rey Católico ${ }^{35}$. De entre todas ellas, como destacábamos en las páginas precedentes, las referencias a las bodas del príncipe don Juan de Trastámara suponen un testimonio de una riqueza excepcional. Sin obviar el importante carácter dinástico de la celebración, sobre el que volveremos, en un primer momento resulta imprescindible destacar que las celebraciones provocaron una distorsión en el recorrido que venimos detallando. Acorde con la ocasión, observamos una distribución de libreas por extenso en casi toda la Corte, lo que nos permite conocer la relación entre el rey y sus cortesanos en un nuevo contexto.

34 La bibliografía sobre la fiesta medieval resulta sumamente extensa. Ante la falta de espacio nos remitimos a la analizada en el trabajo de Ladero Quesada, Miguel Ángel. Las fiestas en la Europa medieval. Madrid: Dykinson, 2015.

35 Si nos limitamos a la Corte de Fernando II, no sorprende el pago del vestuario a determinados cortesanos en las segundas nupcias del rey, o en otros momentos de especial relevancia política como su entrada triunfal en Nápoles, respectivamente reflejados en ACA, PR, MR, Vol. 877, fols. 42v-43r y 74v. 
LAS LIBREAS EN EL SÉQUITO DE FERNANDO EL CATÓLICO: RELACIONES

Y REPRESENTACIONES DE LOS PODERES CORTESANOS

GERMÁN GAMERO IGEA

En efecto, la Corte debía participar del ornato de la monarquía en esta celebración. No obstante, la pregunta reside en los términos en los que debía hacerlo. Para explorar esta relación, el código cromático se muestra como un indicador evidente, más para sus ojos que para los nuestros, de la consideración concedida a la Corte y a los cortesanos en estos festejos. Así, el color muestra una de las consideraciones más importantes sobre las que pivotará nuestro análisis: la consideración de la Corte en sí misma, y no como prolongación del soberano. Así pues, ahora debemos desterrar, o al menos matizar, gran parte de las ideas expresadas en el apartado precedente. No observamos una distinción radical entre los departamentos «domésticos» y administrativos. Tampoco resulta evidente una centralidad del rey, sino de las Ordinacions, en la valoración (cromática y económica) de las telas. Guiándonos siempre por el color y su precio, habría que distinguir tres grandes tonalidades empleadas en las libreas. La primera se corresponde con los tonos rojizos, signo de distinción. En un segundo grupo nos encontraríamos con las moradas, que caracterizan a los puestos intermedios. Finalmente, las parduzcas, menos apreciadas por los códigos de la época, se extenderían entre el resto de oficiales de la Corte $^{36}$. Prácticamente ninguna de ellas es absoluta en un solo cortesano. Por el contrario, lo más habitual es encontrarlas combinadas con otros colores, ya sea entre ellos, ya con otros nuevos, como el negro o en menor medida el verde oscuro ${ }^{37}$.

En cuanto a las libreas de tonos rojos, gozaban de la mejor posición en el código cromático bajomedieval para sobresalir en estos festejos. Los motivos son varios pudiendo destacar el carácter icónico del color respecto al poder, así como su adecuación a las fechas en las que tuvo lugar el enlace (domingo de Pentecostés) ${ }^{38}$. Por ello, y como ejemplo de organización vertical a partir del color, se estableció una clara correspondencia entre esta gama y los oficiales «mayores». El Mayordomo Mayor, el Camarero, el Vicecanciller y el binomio Tesorero General-Escribano de Ración ostentaron estos colores $^{39}$. Sin embargo, no todos lo hicieron con la misma intensidad ni formaron un grupo exclusivo. Para reforzar incluso más la distorsión que venimos señalando frente a las libreas ordinarias, no fueron ni el representante de la Cancillería ni el de la Casa los que brillaron en el reparto de las libreas. Por el contrario, fueron los gestores económicos los que más claramente se vieron agraciados en el reparto de las telas ${ }^{40}$. Esta conclusión

36 Sánchez Ortiz, Alicia. «El color: símbolo de poder y orden social. Apuntes para una historia de las apariencias en Europa». Espacio, Tiempo y Forma. Serie IV. Historia Moderna, 1999, vol. 12, pp. 321-354; y GonzÁlez ArCe, José Damián. Apariencia y poder: la legislación suntuaria castellana en los siglos XIII y XV. Jaén: Universidad de Jaén, 1998.

${ }_{37}$ Véanse tablas 1 y 2 del apéndice.

38 Sobre el color rojo y su vinculación con la liturgia, además de las referencias ya citadas, véase Pastoureau, Michel. «Nacimiento de un mundo en blanco y negro: la Iglesia y el color, de los orígenes a la Reforma». En ÍDem. Una Historia simbólica de la Edad Media. Buenos Aires: Katz, 2006, pp. 147-234.

39 Véase tabla 1.

40 No hace falta destacar que todos ellos eran considerados como las cabezas rectoras de sus respectivos departamentos, según las Ordinacions. Pensemos que personajes como los De Espés, nobles principales de Aragón, Mayordomos Mayores de Fernando II, que habían acompañado al rey desde su tierna infancia y que gobernaron Sicilia en momentos todavía complejos para la isla tras la muerte de Juan II, no recibieron un trato tan favorable. Valga el caso de la mayordomía como ejemplo, pues otros 
se desprende del hecho de que sus vestidos debieron ser en su totalidad rojos, y de que, además, no se limitaron solo a sus personas. También sus mujeres e hijos recibieron con la misma prolijidad vestidos para el evento ${ }^{41}$.

Tras los oficiales «mayores» un segundo grupo que destaca por el uso del rojo es el de los maestresalas o, siendo más precisos, aquellos que aparecen como maestresalas en el pago concreto de esta librea. Su posición cromática se encuentra ampliamente justificada por su preeminencia en la mesa regia y en los banquetes que se sucedieron durante las celebraciones ${ }^{42}$. Sin embargo, para el caso de la Corte aragonesa resulta una noticia especialmente relevante por el carácter ajeno del oficio, que en este caso se complementa por la posición tan elevada de sus integrantes. Así, podemos dar noticia de nada menos que de cuatro miembros de la familia Rojas (de los que es sabido que poco después alcanzarían la mayordomía en la Corte de Fernando II) junto con don Fernando de Toledo, Juan Enríquez de Arellano e Ińigo de Mendoza ${ }^{43}$. Es decir, se trata de una nómina de oficiales castellanos, al igual que el oficio. Seguramente debamos considerar estas referencias a la hora de interpretar la ausencia de oficiales tan importantes para la tradición aragonesa como lo era la figura del copero, del cual nada se dice en las libreas de la Escribanía de Ración ${ }^{44}$.

Tras estos grandes personajes tendríamos que considerar los vestuarios caracterizados con los colores morado y pardo. Es posible encontrar libreas que combinan ambos colores o alguno de ellos con el negro o con otras piezas cuyo color no podemos asegurar, como las telas de contray o Londres que en múltiples ocasiones no tienen referencia cromática específica ${ }^{45}$. Como generalización, estos vestuarios eran mucho menos costosos

nobles fieles a Fernando, como fue el caso del marqués de Cádiz, descendiente del gran compañero fernandino de la campaña granadina, recibió un trato incluso más indigno para su estatus como gran noble castellano.

${ }_{41}$ Véase tabla 1. Note el lector familiarizado con las retribuciones en la Corona de Castilla el paralelismo con los Contadores Mayores, que también recibían en sus nóminas los complementos a sus hijos y, en más raras ocasiones, a sus mujeres. Véanse algunos ejemplos en AGS, EMR, Nóminas, Leg. 1, fols. 188, 190 y 325. Incluso, si quisiésemos hacer una distinción entre ambos, sería el Tesorero la cumbre de todo este entramado simbólico, pues su hermano Francisco, elevado al cargo de Despensero Mayor, también recibió un importante lote de sedas carmesíes, e incluso directamente se vio (el Tesorero) privilegiado con una doble librea para sus hijos, caso único en todos los registros, y que no comparten, por tanto, los vástagos del Escribano de Ración.

${ }_{42}$ Sobre los maestresalas puede verse el trabajo de Fernández de Córdova Miralles, La Corte de Isabel I.

43 Todos ellos especificados en la tabla 2.

44 Con ello no queremos afirmar que ese cargo dejase de existir ni que perdiese relevancia. La nómina de coperos es elevada para el reinado de Fernando II y la completan personajes del peso de Antonio de Cardona (ACA, RP, MR, Vol. 920, fol. 115r), Francisco Malferit (Ibidem, fol. 214r) o Guillén Sánchez (Ibídem, Vol. 939, fol. 3v), entre otros. Las causas en la modificación de la etiqueta muy probablemente haya que buscarlas en las ya mencionadas necesidades de compatibilización de la Corte del rey con la de la reina (distinta en oficios, ceremonias y volumen), así como en razones de tipo político y ceremonial especialmente sensibles en el caso de grandes ceremonias como la que nos ocupa.

45 El contray, menos apreciado, tiende a aparecer en la documentación en prendas de abrigo y con referencias a colores oscuros. Un estudio más detallado de estas telas puede verse en GonZÁLEZ 
LAS LIBREAS EN EL SÉQUITO DE FERNANDO EL CATÓLICO: RELACIONES

Y REPRESENTACIONES DE LOS PODERES CORTESANOS

GERMÁN GAMERO IGEA

si los comparamos con lo que venimos describiendo para los grandes cortesanos. Sin perdernos en el detalle, podríamos apuntar que rondarían entre los 10.000 y $4.000 \mathrm{mrs}$, predominando las cantidades intermedias. Además, puede observarse un ligero predominio cromático de los oficiales de la Casa frente a los de la Cámara, pues, mientras que en los primeros predomina el morado, o su combinación con el pardo, en el caso del entorno más personal del rey son los tonos parduzcos los que sobresalen.

Parece que una afirmación de este calado supondría un contrasentido al señalar para el espacio más personal del soberano la consideración (cromática) más baja. Esto puede explicarse por la propia posición ceremonial de la Cámara en estas celebraciones, y sobre todo por su función (o utilidad) para con el resto de la Corte. Los colores mencionados creemos que siguen una lógica interna de la Corte (y no del rey), y no parecen tener en consideración la posición del servicio al soberano, tradicionalmente desatacado como centro del séquito. Pero este comportamiento no es absoluto y la influencia del rey se deja ver en un grupo muy característico. Para ello tendríamos que tener en cuenta un último color, de simbología en alza durante el reinado de los Reyes Católicos: el negro ${ }^{46}$. En la mayoría de libreas este color resulta minoritario. No obstante, cuando ocupa una posición destacada en los vestuarios, adquiere múltiples significados para nuestro estudio. El más relevante resulta su vinculación con la figura regia, como testimonia el caso de los secretarios ${ }^{47}$. De nuevo, es importante destacarlo, encontramos un nuevo matiz en la dinámica inicial que se había planteado para los vestuarios ordinarios. Es cierto que se trata de miembros de la administración, pero no son oficiales representantes del reino (como pudiera ser el canciller), sino de los designios regios. Además, el negro no les identifica con otras élites cortesanas, sino con oficiales tan significativos como los continos, brazo ejecutor de la realeza ${ }^{48}$; los físicos,

Marrero, La Casa de Isabel la Católica. En concreto, para el caso del Rey Católico puede observarse su uso en oficiales de una extracción social media o baja en las tablas 1 y 2 del apéndice de este trabajo.

46 Un reciente estudio sobre el uso del negro en la Corte trastámara en Nogales Rincón, David. «El color negro: luto y magnificencia en la Corona de Castilla (siglos XIII-Xv)». Medievalismo, 2016, vol. 26, pp. 221-245. Sobre su contexto europeo véase Quondam, Tutti i colori del nero.

${ }_{47} \mathrm{El}$ ascenso político de la figura de los secretarios se ha destacado en diferentes ocasiones. Puede destacarse el clásico estudio de Escudero, José Antonio. Los secretarios de Estado y del Despacho (1474-1724). Madrid: Instituto de Estudios Administrativos, 1976; o los más recientes de CAÑAS Gálvez, Francisco de Paula. «García Fernández de Alcalá: notas biográficas y contextos institucionales de un secretario y agente fiscal del rey de Castilla (1440-1467)». En Borrero Fernández, Mercedes; Carrasco Pérez, Juan y Peinado Santaella, Rafael Gerardo (coords.). Agentes de los sistemas fiscales en Andalucía y los reinos hispánicos (siglos XIII-XVI): un modelo comparativo. Madrid: Instituto de Estudios Fiscales, 2014, pp. 67-84; ÍDEM. "Juan de Mena, secretario de latín y cronista del rey: un letrado en la Cancillería Real al servicio de Juan II y Enrique IV». En Moya García, Cristina (coord.). Juan de Mena: de letrado a poeta. Woodbridge: Tamesis Books, 2015, pp. 11-22.

48 Sobre estos oficiales pueden consultarse algunas obras que, además de pretender caracterizar este ambiguo grupo, recogen la bibliografía precedente, tales como EzQUerRa REVILLA, Javier y MarTíNEZ Millán, José. «La integración de las élites sociales en las monarquías dinásticas: los continos». En Espacios de poder: cortes, ciudades y villas. Madrid: Jesús Bravo SL, 2002, pp. 339-380; Gamero IgeA, Germán. «Los continos en el reinado de Fernando el Católico. Oficiales entre la corte y la ciudad». En Carvajal, David; Vitores, Imanol y AÑíbarro, Javier (eds.). Poder, fisco y mercado en las ciudades de la Peninsula Ibérica (siglos XIV-XVI). Valladolid: Castilla Ediciones, 2016, pp. 193-208. 
encargados de su cuerpo ${ }^{49}$; y los aposentadores, encargados de su exposición ante el reino ${ }^{50}$. Todos ellos son grupos (junto con los miembros del Consejo, de los que en este caso nada se dice) pagados por vía de nómina, no de quitación. Que la gestión administrativa coincida, en un momento tan señalado, con una diferenciación visual, tan señalada en lo simbólico, es toda una llamada de atención para el análisis y consideración de estos grupos.

Pero lo más relevante para este trabajo es el uso diferencial de las libreas a la hora de uniformar el séquito regio. La Corte, compuesta por las élites de los reinos, renuncia colectivamente a la expresión de su propio poder individual. Pero también es cierto que lo hacen bajo parámetros tan solo colaterales al poder regio. La celebración extraordinaria, que debería celebrar el culmen de la dinastía, se convierte así en una celebración mucho más compleja. Este reparto de libreas permite observar a la Corte no como un mero apéndice del rey, sino como una institución de poder en sí misma. En estos vestuarios no encontramos una jerarquización en función de la cercanía al soberano, sino de su papel dentro del entramado curial. Se trata por tanto de una visión profundamente política, conectada con esa imagen simbólica del Estado con la que iniciábamos nuestro trabajo.

\section{Conclusiones}

El vestido, un instrumento simbólico capaz de aportar multitud de matices al cuerpo en la sociedad bajomedieval, se muestra como un medio excepcional para conocer las relaciones de poder dentro de la Corte. En el caso del séquito de Fernando II de Aragón hemos podido comprobar cómo pasó de ser una percepción salarial a un instrumento con el que significar el servicio cortesano en los momentos ordinarios de la vida cortesana. En estas situaciones es posible observar el peso del rey tanto en la forma de recibir las libreas como en la selección de los cortesanos que participan del reparto o no. Por el contrario, en los grandes acontecimientos, o al menos en algunos de ellos, observamos cómo el vestuario continúa siendo una muestra del poder cortesano, aunque con consecuencias sustancialmente distintas al mostrar su desvinculación (simbólica) del cuerpo regio.

Así, tanto la noción de S. Bertelli como de A. Stegman aparecen reflejadas en el análisis de este trabajo. A pesar de la relevancia del soberano en la estructuración y control de su séquito, este no es absoluto ni se centra, tampoco, en los espacios que tradicionalmente se consideran más politizados o relevantes desde el punto de vista ceremonial. Además, también la fiesta es capaz de mostrar a la Corte como una estructura en sí misma. En un momento de exaltación dinástica y de creación de imágenes de consenso, la Corte aparece no solo como el espacio regio, sino como imagen del poder del Estado. Esta acepción, que nos maravilla con su fastuosidad y colorido, no podría valorarse en su justa medida si no se pusiera en relación con otros aspectos. Tal es el caso de la función legitimadora de la organización cortesana que se observa tanto en el reinado de Isabel I de Castilla

49 Un estudio clásico sobre estos oficiales puede verse en Alonso Cortés, Narciso. «Dos médicos de los Reyes Católicos». Hispania. Revista Española de Historia, 1951, vol. 45, pp. 607-657.

50 Para una reflexión sobre los aposentadores y su labor en el séquito del Rey Católico, vid. GameRo IGEA, Germán. «Conectar dos mundos: el aposento del séquito de Fernando el Católico». En prensa. 
LAS LIBREAS EN EL SÉQUITO DE FERNANDO EL CATÓLICO: RELACIONES

Y REPRESENTACIONES DE LOS PODERES CORTESANOS

GERMÁN GAMERO IGEA

como en el de Fernando II de Aragón. Pero también resulta necesario contextualizar esta situación con la propia significación de los cortesanos y de sus trayectorias de servicio, campos todavía por explorar en futuras investigaciones.

Por el momento puede concluirse cómo el reparto de textiles no solo participa de la construcción de discursos de tipo político complementarios en el seno de la Corte. Además, es un recurso capaz de englobar situaciones que van de la posición secundaria de los cazadores a la centralidad de los secretarios y gestores económicos. Esta complementariedad y complejidad produce una dinámica mucho más rica que la mera representación mayestática que, lejos de agotarse en este trabajo, puede reportar todavía valiosas reflexiones sobre el comportamiento de la sociedad cortesana.

\section{ApÉNDICE}

Relación de libreas concedidas a los oficiales de la Corte de Fernando el Católico con motivo del matrimonio del príncipe don Juan en $1497^{51}$.

Tabla 1. Oficiales contemplados en las Ordinacions de Pedro el Ceremonioso ${ }^{52}$.

\begin{tabular}{|c|c|c|}
\hline Cargo & Oficial & Librea \\
\hline \multirow[t]{2}{*}{ Mayordomo mayor } & Don Ramón de Espés & \multirow{2}{*}{$\begin{array}{l}29 \text { varas de terciopelo carmesí } \\
8 \text { varas de terciopelo negro } \\
7 \text { varas de ceutí morado } \\
2 \text { varas de ceutí carmesí } \\
\end{array}$} \\
\hline & Su mujer & \\
\hline Mayordomo & Don Pedro de Hoces & $\begin{array}{l}6 \text { varas y } 1 / 2 \text { de terciopelo negro } \\
6 \text { varas de contray de Flandes } \\
2 \text { varas de ceutí carmesí }\end{array}$ \\
\hline Mozo de copa & Juan de Salvatierra & $\begin{array}{l}7 \text { varas de Londres morado } \\
2 \text { varas de ceutí morado de Valencia }\end{array}$ \\
\hline Ayudante de copa & Juan de Avecia & $\begin{array}{l}5 \text { varas de trapo morado de Valencia } \\
2 \text { varas de terciopelo negro } \\
2 \text { varas de grana de Londres }\end{array}$ \\
\hline Botellero & Alonso de Lagarza & $\begin{array}{l}8 \text { varas de terciopelo negro } \\
5 \text { varas de contray de Flandes }\end{array}$ \\
\hline Panadera & Teresa Muñoz & $\begin{array}{l}4 \text { varas de contray de Flandes } \\
4 \text { varas y } 1 / 2 \text { de Londres } \\
1 \text { chamelote }\end{array}$ \\
\hline Ayudante de la panadera & María Senil & $\begin{array}{l}4 \text { varas de contray de Flandes } \\
4 \text { varas de Londres } \\
1 \text { chamelote }\end{array}$ \\
\hline Pastelera («la que amasa el pan») & María Gutiérrez & $\begin{array}{l}4 \text { varas de contray de Flandes } \\
4 \text { varas de Londres } \\
1 \text { chamelote negro }\end{array}$ \\
\hline
\end{tabular}

51 Para la confección de estas tablas se han empleado las noticias extraídas del registro ACA, RP, MR, Vol. 876, fols. 60r-97r.

52 El orden empleado es el más semejante posible al propuesto por el texto. 
LAS LIBREAS EN EL SÉQUITO DE FERNANDO EL CATÓLICO: RELACIONES Y REPRESENTACIONES DE LOS PODERES CORTESANOS

\begin{tabular}{|c|c|c|}
\hline Cargo & Oficial & Librea \\
\hline \multirow{2}{*}{ Trinchante } & Don Francisco de Monpalau & \multirow{2}{*}{$\begin{array}{l}17 \text { varas de terciopelo negro } \\
12 \text { varas de terciopelo carmesí } \\
8 \text { varas de terciopelo morado } \\
7 \text { varas de ceutí morado } \\
2 \text { varas de ceutí carmesí }\end{array}$} \\
\hline & Su mujer & \\
\hline Trinchante & Mosén Fernando de Rebolledo & \begin{tabular}{|l}
17 varas de terciopelo carmesí \\
2 varas de ceutí carmesí
\end{tabular} \\
\hline \multirow[t]{2}{*}{ Cocinero } & Martín de Leache & $\begin{array}{l}5 \text { varas de Londres morado } \\
2 \text { varas de terciopelo negro } \\
2 \text { varas de grana morada }\end{array}$ \\
\hline & Su mujer & $\begin{array}{l}4 \text { varas de contray de Flandes } \\
4 \text { varas de Londres } \\
1 \text { chamelote negro }\end{array}$ \\
\hline Despensero mayor & Francisco Sánchez & 24 varas de altibajo carmesí \\
\hline Despensero & Alonso de Formicedo & $\begin{array}{l}7 \text { varas de Londres } \\
1 \text { vara y } 1 / 2 \text { de ceutí negro } \\
1 / 2 \text { vara de terciopelo negro }\end{array}$ \\
\hline \multirow[t]{4}{*}{ Mozos de cocina } & Fernando de Rivadeneira & \multirow{2}{*}{$\begin{array}{l}\text { A cada uno: } \\
5 \text { varas de Londres } \\
2 \text { varas de terciopelo negro } \\
2 \text { varas de grana morada }\end{array}$} \\
\hline & Martín Diez & \\
\hline & Juan Baget & \multirow{2}{*}{$\begin{array}{l}\text { A cada uno: } \\
7 \text { varas de Londres } \\
1 / 2 \text { vara de terciopelo negro } \\
1 \text { florín } \\
\end{array}$} \\
\hline & Juan Oteo & \\
\hline Aguador & Martín de Ocharín & $\begin{array}{l}7 \text { varas de Londres pardo } \\
1 / 2 \text { vara de terciopelo negro } \\
1 \text { florín }\end{array}$ \\
\hline \multirow[t]{4}{*}{ Ayudantes de la despensa } & Diego de la Peña & \multirow{4}{*}{$\begin{array}{l}\text { A cada uno: } \\
7 \text { varas de Londres } \\
1 / 2 \text { vara de ceutí negro } \\
1 \text { florín para un gibón }\end{array}$} \\
\hline & Iñigo & \\
\hline & Santa Cruz & \\
\hline & Sopena & \\
\hline \multirow[t]{2}{*}{ Regatón } & Álvaro de Cos & $\begin{array}{l}7 \text { varas y } 1 / 4 \text { de Londres } \\
2 \text { varas de terciopelo morado }\end{array}$ \\
\hline & Su mujer & $\begin{array}{l}4 \text { varas de contray de Flandes } \\
4 \text { varas de Londres } \\
1 \text { chamelote }\end{array}$ \\
\hline Contador de la despensa & Antonio Ruiz & $\begin{array}{l}8 \text { varas y } 1 / 2 \text { de terciopelo negro } \\
6 \text { varas de contray de Flandes }\end{array}$ \\
\hline Veedor de la despensa & Juan de Nájera & $\begin{array}{l}8 \text { varas y } 1 / 2 \text { de terciopelo negro } \\
6 \text { varas de contray de Flandes }\end{array}$ \\
\hline \multirow[t]{2}{*}{ Caballerizo } & Pedro Marañón & \multirow{2}{*}{$\begin{array}{l}10 \text { varas de terciopelo negro } \\
6 \text { varas y } 1 / 2 \text { de terciopelo carmesi } \\
4 \text { varas de contray de Flandes }\end{array}$} \\
\hline & Su mujer & \\
\hline Lugarteniente de Caballerizo & Pedro Marañón & \begin{tabular}{|l|}
12 varas de terciopelo negro \\
2 varas de ceutí carmesí
\end{tabular} \\
\hline Ayudante de Caballerizo & Bartolomé Toscano & $\begin{array}{l}8 \text { varas de terciopelo negro } \\
5 \text { varas de contray de Flandes }\end{array}$ \\
\hline
\end{tabular}


LAS LIBREAS EN EL SÉQUITO DE FERNANDO EL CATÓLICO: RELACIONES

Y REPRESENTACIONES DE LOS PODERES CORTESANOS

\begin{tabular}{|c|c|c|}
\hline Cargo & Oficial & Librea \\
\hline «De la Caballeriza» & Çiordia & \multirow{3}{*}{$\begin{array}{l}\text { A cada uno: } \\
7 \text { varas de contray de Flandes } \\
2 \text { varas de terciopelo negro }\end{array}$} \\
\hline Sillero & Francisco de Paz & \\
\hline \multirow[t]{2}{*}{ Frenero } & Juan de Burgos & \\
\hline & Su mujer & $\begin{array}{l}4 \text { varas de contray de Flandes } \\
4 \text { varas de Londres } \\
1 \text { chamelote }\end{array}$ \\
\hline Albéitar & Beltrán Carance & $\begin{array}{l}7 \text { varas de Londres } \\
2 \text { varas de terciopelo negro }\end{array}$ \\
\hline Herrador & Diego de Zamora & $\begin{array}{l}7 \text { varas de Londres } \\
2 \text { varas de ceutí negro }\end{array}$ \\
\hline Mozos de caballeriza & (hasta 11, sin nombre) & $\begin{array}{l}\text { A cada uno: } \\
1 / 2 \text { manga de gibón de fustán de } \\
\text { terciopelo negro } \\
1 \text { capuzo } \\
1 \text { sayo de Londres pardo y morado }\end{array}$ \\
\hline \multirow[t]{13}{*}{ Hombres de pie } & Juan Ferriol & \multirow{13}{*}{$\begin{array}{l}\text { A cada uno: } \\
7 \text { varas de Londres morado y pardo } \\
1 / 2 \text { vara de terciopelo negro } \\
1 \text { florín }\end{array}$} \\
\hline & Pedro de Cáceres & \\
\hline & Juan Navarro & \\
\hline & Pedro de Agüero & \\
\hline & Juan de Guzmán & \\
\hline & Sancho Calderón & \\
\hline & Alonso Carrión & \\
\hline & Pedro de Mota & \\
\hline & Pedro de Cuero & \\
\hline & Alonso Fajardo & \\
\hline & Bernardo de Benavente & \\
\hline & Juan Navarro (II) & \\
\hline & Nicolás Siciliano & \\
\hline Cazador mayor & Carlos de Chauz & $\begin{array}{l}12 \text { varas de terciopelo negro } \\
2 \text { varas de ceutí carmesí }\end{array}$ \\
\hline Cazador & Pedro de Chauz & $\begin{array}{l}6 \text { varas y y 1/2 de terciopelo negro } \\
2 \text { varas de ceutí carmesí }\end{array}$ \\
\hline Mozo de Cazador & Fernando de Santa Fe & $\begin{array}{l}7 \text { varas de Londres } \\
2 \text { varas de ceutí negro } \\
\end{array}$ \\
\hline Acemilero Mayor & Rodrigo de Losada & $\begin{array}{l}8 \text { varas de terciopelo negro } \\
6 \text { varas de contray de Flandes }\end{array}$ \\
\hline \multirow[t]{8}{*}{ Trompetas } & Alonso de Ávila & \multirow{8}{*}{$\begin{array}{l}\text { A cada uno: } \\
1 \text { gibón de terciopelo negro } \\
1 \text { capuzo de grana } \\
1 \text { sayo de tela de Londres morado }\end{array}$} \\
\hline & Alonso de Iniesta & \\
\hline & Alonso de Uceda & \\
\hline & García de Toledo & \\
\hline & Juan de Aguilera & \\
\hline & Juan de Urso & \\
\hline & Pedro Ansúrez de Ávila & \\
\hline & Rodrigo d'Urso & \\
\hline
\end{tabular}


LAS LIBREAS EN EL SÉQUITO DE FERNANDO EL CATÓLICO: RELACIONES

\begin{tabular}{|c|c|c|}
\hline Cargo & Oficial & Librea \\
\hline \multirow[t]{4}{*}{ Atabaleros } & Cristóbal el Negro & \multirow{4}{*}{$\begin{array}{l}\text { A cada uno: } \\
1 \text { gibón de terciopelo verde y pardo } \\
1 \text { capuzo de tela de Londres morado } \\
1 \text { sayo de tela de Londres verde y pardo }\end{array}$} \\
\hline & Diego de Anequín & \\
\hline & Juan de Abella & \\
\hline & \begin{tabular}{|l|} 
Juan de Segovia \\
\end{tabular} & \\
\hline \multirow[t]{8}{*}{ Ministriles } & Bartolomé Gaço & \multirow{8}{*}{$\begin{array}{l}\text { A cada uno: } \\
1 \text { gibón de terciopelo negro } \\
1 \text { capuzo de grana } \\
1 \text { sayo de tela de Londres morado }\end{array}$} \\
\hline & Francisco Gaço & \\
\hline & Jorge de Bolańos & \\
\hline & Juan Gaço & \\
\hline & Juan Ginés & \\
\hline & Juan Pérez de Mesa & \\
\hline & Sebastián Gaço & \\
\hline & Pedro de Toledo & \\
\hline \multirow[t]{2}{*}{ Camarero } & Juan Cabrero & $\begin{array}{l}17 \text { varas de altibajo carmesí } \\
2 \text { varas y } 1 / 4 \text { de ceutí carmesí }\end{array}$ \\
\hline & Su mujer & $\begin{array}{l}12 \text { varas de terciopelo carmesí } \\
8 \text { varas de terciopelo "morado carmesí» } \\
7 \text { varas de ceutí morado }\end{array}$ \\
\hline \multirow[t]{2}{*}{ Ayudante de cámara } & Hernando de Vega & $\begin{array}{l}5 \text { varas de contray de Flandes } \\
2 \text { varas de grana } \\
2 \text { varas de terciopelo negro }\end{array}$ \\
\hline & Su mujer & $\begin{array}{l}8 \text { varas de terciopelo negro } \\
4 \text { varas de contray de Flandes }\end{array}$ \\
\hline \multirow[t]{14}{*}{ Escuderos de cámara } & Fernando de Hoyos & $\begin{array}{l}5 \text { varas y } 1 / 4 \text { de trapo pardo de Valencia } \\
2 \text { varas y } 1 / 4 \text { de grana } \\
2 \text { varas de terciopelo negro }\end{array}$ \\
\hline & Francisco de Medina & $\begin{array}{l}2 \text { varas de grana } \\
2 \text { varas de terciopelo negro } \\
1 / 2 \text { vara de trapo pardo de Valencia }\end{array}$ \\
\hline & Su mujer & $\begin{array}{l}4 \text { varas de contray de Flandes } \\
4 \text { varas de Londres }\end{array}$ \\
\hline & Diego de Soto & \multirow{5}{*}{$\begin{array}{l}\text { A cada uno: } \\
5 \text { varas de trapo morado de Valencia } \\
2 \text { varas de grana } \\
2 \text { varas de terciopelo negro }\end{array}$} \\
\hline & Gonzalo de Alderete & \\
\hline & Juan de Villaplana & \\
\hline & Juan Ruiz & \\
\hline & Ramón de Sesé & \\
\hline & Bernardino de Torre & \multirow{6}{*}{$\begin{array}{l}\text { A cada uno: } \\
5 \text { varas de trapo pardo de Valencia } \\
2 \text { varas de grana } \\
2 \text { varas de terciopelo negro }\end{array}$} \\
\hline & Gaspar de Montesa & \\
\hline & Juan de Soria & \\
\hline & Martín de Bin & \\
\hline & Mateo de Soria & \\
\hline & Nicolás de Infant & \\
\hline Mozo de las armas & García López de Vega & $\begin{array}{l}5 \text { varas de trapo pardo de Valencia } \\
2 \text { varas de grana } \\
2 \text { varas de terciopelo negro }\end{array}$ \\
\hline
\end{tabular}


LAS LIBREAS EN EL SÉQUITO DE FERNANDO EL CATÓLICO: RELACIONES

Y REPRESENTACIONES DE LOS PODERES CORTESANOS

\begin{tabular}{|c|c|c|}
\hline Cargo & Oficial & Librea \\
\hline Mozo del bacín & Pedro de Montego & $\begin{array}{l}5 \text { varas de Londres pardo } \\
2 \text { varas de grana } \\
2 \text { varas de terciopelo negro }\end{array}$ \\
\hline Brasero & Francisco de Ledesma & $\begin{array}{l}7 \text { varas de Londres } \\
2 \text { varas de ceutí tenat } \\
\end{array}$ \\
\hline \multirow[t]{15}{*}{ Ayudantes de Cámara } & Cristóbal de Robles & $\begin{array}{l}6 \text { varas de contray de Flandes } \\
2 \text { varas de terciopelo negro }\end{array}$ \\
\hline & Diego de las Osas & $\begin{array}{l}8 \text { varas y } 1 / 3 \text { de trapo morado de } \\
\text { Valencia } \\
2 \text { varas de terciopelo negro }\end{array}$ \\
\hline & Francisco de Vera & $\begin{array}{l}7 \text { varas y } 1 / 2 \text { de trapo verde de Valencia } \\
2 \text { varas de terciopelo negro }\end{array}$ \\
\hline & Jaime de Ruidolms & $\begin{array}{l}6 \text { vara de contray de Flandes } \\
2 \text { varas y } 1 / 2 \text { de contray de Valencia } \\
2 \text { varas de terciopelo negro }\end{array}$ \\
\hline & Juan de Alfaro & $\begin{array}{l}5 \text { varas de Londres pardo } \\
2 \text { varas y } 1 / 2 \text { de contray de Valencia } \\
2 \text { varas de terciopelo negro }\end{array}$ \\
\hline & Juan de Morales & $\begin{array}{l}5 \text { varas de Londres pardo } \\
3 \text { varas de trapo verde oscuro de Valencia } \\
2 \text { varas de terciopelo negro }\end{array}$ \\
\hline & Miguel de Arasso & $\begin{array}{l}8 \text { varas de terciopelo negro } \\
6 \text { varas de contray de Valencia }\end{array}$ \\
\hline & Pedro de Cenicero & $\begin{array}{l}7 \text { varas de contray de Flandes } \\
2 \text { varas de terciopelo negro } \\
\end{array}$ \\
\hline & Pedro de Diaques & $\begin{array}{l}8 \text { varas y } 1 / 2 \text { de terciopelo negro } \\
6 \text { varas de contray de Valencia }\end{array}$ \\
\hline & Pedro de Iborra & $\begin{array}{l}5 \text { varas y } 1 / 2 \text { de Londres pardo } \\
2 \text { varas y } 2 / 3 \text { de contray de Valencia } \\
2 \text { varas de terciopelo negro }\end{array}$ \\
\hline & Pedro de Porras & $\begin{array}{l}8 \text { varas y } 1 / 3 \text { de trapo morado de Valencia } \\
2 \text { varas de terciopelo negro }\end{array}$ \\
\hline & Pedro de San Román & $\begin{array}{l}5 \text { varas de Londres pardo } \\
2 \text { varas y } 2 / 3 \text { de contray de Valencia } \\
2 \text { varas de terciopelo negro } \\
\end{array}$ \\
\hline & Pedro de Tuscany & $\begin{array}{l}5 \text { varas y } 1 / 2 \text { de Londres pardo } \\
3 \text { varas de trapo verde oscuro de } \\
\text { Valencia } \\
2 \text { varas de terciopelo negro }\end{array}$ \\
\hline & Tordesillas & $\begin{array}{l}7 \text { varas y } 1 / 2 \text { de trapo pardo de Valencia } \\
2 \text { varas de terciopelo negro }\end{array}$ \\
\hline & Zuazo & $\begin{array}{l}7 \text { varas y } 1 / 2 \text { de trapo pardo de Valencia } \\
2 \text { varas de terciopelo negro }\end{array}$ \\
\hline \multirow[t]{2}{*}{ Barbero } & Francisco de Palacios & $\begin{array}{l}5 \text { varas de trapo pardo de Valencia } \\
2 \text { varas de grana de Valencia } \\
2 \text { varas de terciopelo negro }\end{array}$ \\
\hline & Su mujer & $\begin{array}{l}4 \text { varas de contray de Flandes } \\
4 \text { varas de Londres } \\
1 \text { chamelote }\end{array}$ \\
\hline
\end{tabular}


LAS LIBREAS EN EL SÉQUITO DE FERNANDO EL CATÓLICO: RELACIONES Y REPRESENTACIONES DE LOS PODERES CORTESANOS

\begin{tabular}{|c|c|c|}
\hline Cargo & Oficial & Librea \\
\hline Médico & Maestro Nicolás & $\begin{array}{l}8 \text { varas de terciopelo negro } \\
6 \text { varas de contray de Valencia } \\
2 \text { varas de ceutí carmesí }\end{array}$ \\
\hline «Doctor de la reina» & Gabriel Álvarez & $\begin{array}{l}16 \text { varas de terciopelo negro } \\
8 \text { varas } \mathrm{y}^{7} / 12 \text { de terciopelo morado } \\
\text { carmesí } \\
2 \text { varas } \mathrm{y}^{2} / 12 \text { de ceutí carmesí }\end{array}$ \\
\hline \multirow[t]{3}{*}{ Cirujanos } & Alfonso de Guadalupe & $\begin{array}{l}8 \text { varas de terciopelo negro } \\
6 \text { varas de contray de Flandes } \\
2 \text { varas } \mathrm{y}^{2} / 12 \text { de ceutí carmesí }\end{array}$ \\
\hline & Alonso de Santiago & $\begin{array}{l}6 \text { varas de contray de Flandes } \\
2 \text { varas y } 1 / 4 \text { de grana de Valencia } \\
2 \text { varas de terciopelo negro }\end{array}$ \\
\hline & Juan de Herrera & $\begin{array}{l}8 \text { varas de terciopelo negro } \\
6 \text { varas de contray de Flandes } \\
2 \text { varas de ceutí morado }\end{array}$ \\
\hline \multirow[t]{2}{*}{ Secretario } & Juan de Coloma & $\begin{array}{l}14 \text { varas de terciopelo negro } \\
8 \text { varas de aceituní carmesí } \\
2 \text { varas de ceutí carmesí }\end{array}$ \\
\hline & Su mujer & $\begin{array}{l}12 \text { varas de terciopelo carmesí } \\
8 \text { varas de terciopelo morado carmesí } \\
7 \text { varas de ceutí morado }\end{array}$ \\
\hline \multirow[t]{3}{*}{ Secretarios } & Luis González & \multirow{3}{*}{$\begin{array}{l}\text { A cada uno: } \\
14 \text { varas de terciopelo negro } \\
8 \text { varas de aceituní carmesí } \\
2 \text { varas de ceutí carmesí }\end{array}$} \\
\hline & Miguel Pérez de Almazán & \\
\hline & Miguel Velázquez Climent & \\
\hline Armero & Pedro & $\begin{array}{l}5 \text { varas de trapo pardo de Valencia } \\
2 \text { varas de grana de Londres } \\
2 \text { varas de terciopelo negro } \\
\end{array}$ \\
\hline \multirow[t]{2}{*}{ Maestro de hacer tiendas } & Vicente Çahera & $\begin{array}{l}5 \text { varas de trapo pardo de Valencia } \\
2 \text { varas de aceituní negro } \\
2 \text { varas y } 1 / 4 \text { de trapo verde de Valencia }\end{array}$ \\
\hline & Su mujer & $\begin{array}{l}4 \text { varas de contray de Flandes } \\
4 \text { varas de Londres } \\
1 \text { chamelote }\end{array}$ \\
\hline \multirow[t]{2}{*}{ Sastre } & Menaute de la Cabra & \multirow{2}{*}{$\begin{array}{l}16 \text { varas y } 1 / 2 \text { de terciopelo negro } \\
10 \text { varas y } 1 / 2 \text { de contray de Valencia } \\
7 \text { varas y } 1 / 2 \text { de terciopelo blanco } \\
2 \text { varas y } 1 / 2 \text { de terciopelo morado } \\
1 \text { chamelote } \\
\end{array}$} \\
\hline & Su mujer y dos hijos & \\
\hline Costurera & Isabel Guillem & $\begin{array}{l}4 \text { varas de contray de Valencia } \\
4 \text { varas y } 1 / 2 \text { de trapo verde de Valencia } \\
1 \text { pieza de chamelote }\end{array}$ \\
\hline \multirow[t]{2}{*}{ Bordador } & Pedro & $\begin{array}{l}5 \text { varas de Londres morado } \\
2 \text { varas de grana morada de Londres } \\
2 \text { varas de terciopelo negro }\end{array}$ \\
\hline & Su mujer & $\begin{array}{l}4 \text { varas de Londres } \\
3 \text { varas y } 2 / 3 \text { de contray de Flandes } \\
1 \text { pieza de chamelote }\end{array}$ \\
\hline Bordador & Juan de Bilbao & $\begin{array}{l}7 \text { varas de Londres pardo } \\
1 / 2 \text { vara de terciopelo negro } \\
1 \text { florín }\end{array}$ \\
\hline
\end{tabular}


LAS LIBREAS EN EL SÉQUITO DE FERNANDO EL CATÓLICO: RELACIONES

Y REPRESENTACIONES DE LOS PODERES CORTESANOS

\begin{tabular}{|c|c|c|}
\hline Cargo & Oficial & Librea \\
\hline Cordonero & Gonzalo Dapila (sic) & $\begin{array}{l}5 \text { varas de Londres morado } \\
2 \text { varas de aceituní negro } \\
2 \text { varas y } 1 / 4 \text { de contray de Flandes }\end{array}$ \\
\hline \multirow[t]{2}{*}{ Cordoneros Moros } & Mohamed & \multirow{2}{*}{$\begin{array}{l}\text { A cada uno: } \\
7 \text { varas de Londres morado } \\
1 / 2 \text { vara de aceituní negro } \\
1 \text { florín }\end{array}$} \\
\hline & Çaçim & \\
\hline Pellicer & Marcial de Ruena & $\begin{array}{l}7 \text { varas de trapo pardo y verde de } \\
\text { Valencia } \\
2 \text { varas de terciopelo negro }\end{array}$ \\
\hline \multirow[t]{2}{*}{ Zapatero } & Jaime (Domenec) & \multirow{2}{*}{$\begin{array}{l}9 \text { varas de contray de Flandes } \\
4 \text { varas de grana morada } \\
2 \text { varas de grana de Londres } \\
2 \text { varas de terciopelo negro } \\
1 \text { chamelote }\end{array}$} \\
\hline & Su mujer & \\
\hline \multirow[t]{2}{*}{ Lavandera } & Juana de Viana & $\begin{array}{l}4 \text { varas de contray de Flandes } \\
4 \text { varas de Londres } \\
1 \text { pieza de chamelote }\end{array}$ \\
\hline & Tres hijos suyos & $\begin{array}{l}10 \text { varas y } 1 / 2 \text { de Londres } \\
7 \text { reales }\end{array}$ \\
\hline Apotecario & Mosén Jaime Pascual & $\begin{array}{l}6 \text { varas de contray de Flandes } \\
2 \text { varas y } 1 / 2 \text { de trapo verde de Valencia } \\
2 \text { varas de terciopelo negro }\end{array}$ \\
\hline Cerero & Zurita & $\begin{array}{l}7 \text { varas y } 1 / 2 \text { de trapo verde oscuro de } \\
\text { Venecia } \\
2 \text { varas y } 1 / 7 \text { de aceituní negro }\end{array}$ \\
\hline \multirow[t]{2}{*}{ Ayudantes del Cerero } & Gonzalo de Río & $\begin{array}{l}5 \text { varas de trapo verde oscuro de Venecia } \\
2 \text { varas de aceituní negro } \\
2 \text { varas de contray de Flandes }\end{array}$ \\
\hline & Sancho de Lanas & $\begin{array}{l}5 \text { varas de Londres } \\
2 \text { varas y } 1 / 3 \text { de contray de Flandes } \\
2 \text { varas de terciopelo negro }\end{array}$ \\
\hline \multirow[t]{4}{*}{ Reposteros mayores } & Diego de Aramayo & \multirow{3}{*}{$\begin{array}{l}\text { A cada uno } \\
5 \text { varas de trapo morado de Valencia } \\
2 \text { varas de grana de Londres } \\
2 \text { varas de terciopelo negro } \\
\end{array}$} \\
\hline & Pedro Valenciano & \\
\hline & Pedro de Verastegui & \\
\hline & Martín Navarro & $\begin{array}{l}7 \text { varas de trapo verde de Valencia } \\
2 \text { varas de terciopelo negro }\end{array}$ \\
\hline Mozo de Plata & Juan de Cavalla & $\begin{array}{l}6 \text { varas de Londres morado } \\
2 \text { varas de ceutí morado de Valencia }\end{array}$ \\
\hline \multirow[t]{9}{*}{ Reposteros comunes } & Álvaro de Andía & \multirow{9}{*}{$\begin{array}{l}\text { A cada uno: } \\
5 \text { varas de Londres morado y pardo } \\
2 \text { varas de grana } \\
2 \text { varas de terciopelo negro }\end{array}$} \\
\hline & Bernardino de Vera & \\
\hline & Bernardino de Valladolid & \\
\hline & Cristóbal Zapata & \\
\hline & Francisco de Hontiveros & \\
\hline & Gómez de la Serna & \\
\hline & Juan de Zamudio & \\
\hline & Juan Fernández & \\
\hline & Juan de Guzmán & \\
\hline
\end{tabular}


LAS LIBREAS EN EL SÉQUITO DE FERNANDO EL CATÓLICO: RELACIONES

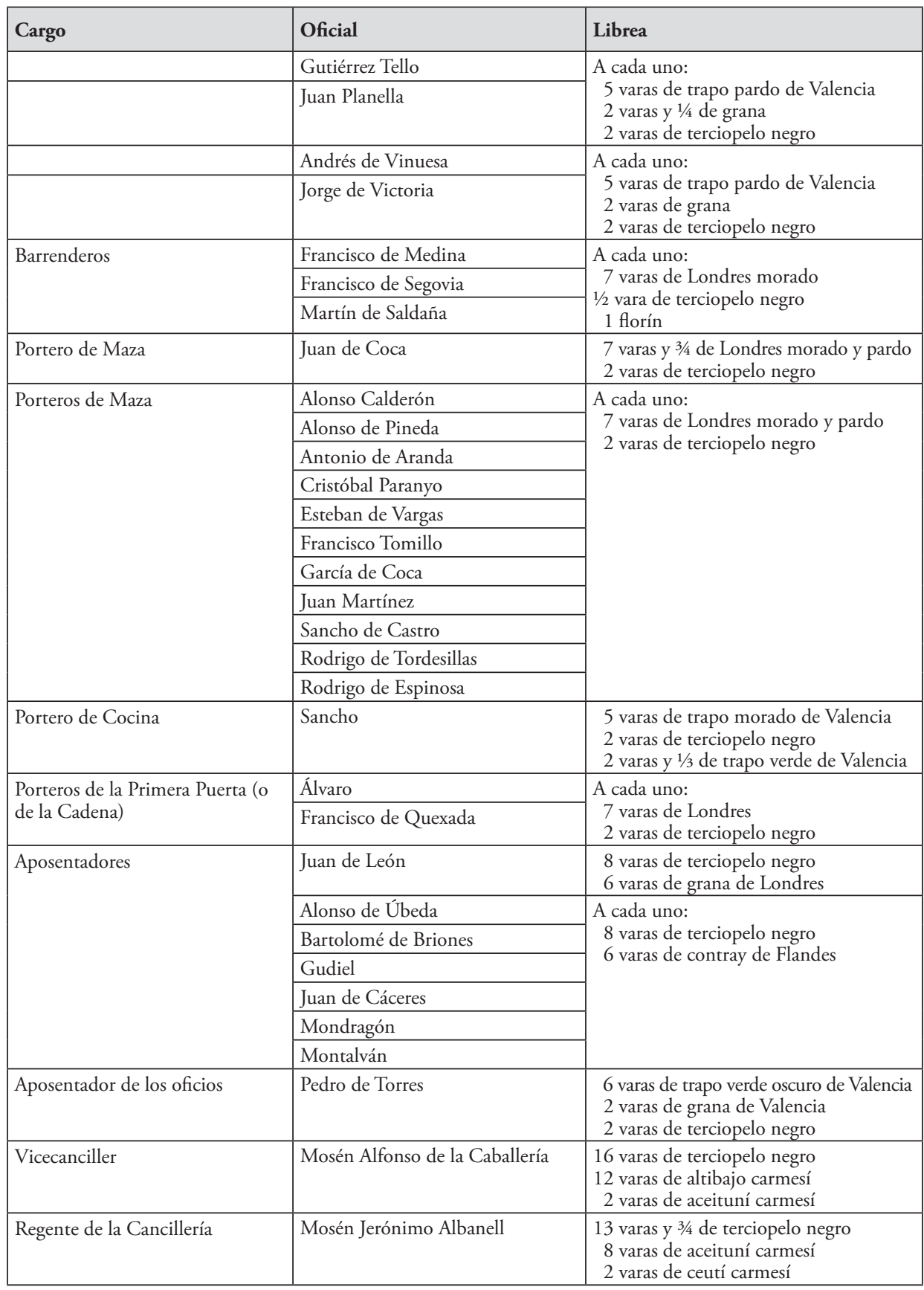


LAS LIBREAS EN EL SÉQUITO DE FERNANDO EL CATÓLICO: RELACIONES

Y REPRESENTACIONES DE LOS PODERES CORTESANOS

\begin{tabular}{|c|c|c|}
\hline Cargo & Oficial & Librea \\
\hline \multirow[t]{2}{*}{$\begin{array}{l}\text { Regentes de la Cancillería y } \\
\text { consejeros }\end{array}$} & Mosén Felipe Pons & $\begin{array}{l}13 \text { varas y } 10 / 12 \text { de terciopelo negro } \\
10 \text { varas de aceituní carmesí } \\
2 \text { varas de ceutí carmesí }\end{array}$ \\
\hline & Mosén Tomás Malferit & $\begin{array}{l}14 \text { varas de terciopelo negro } \\
8 \text { varas de aceituní carmesí } \\
2 \text { varas de ceutí carmesí }\end{array}$ \\
\hline Peticionero de la Cancillería & Jaime Verguer & $\begin{array}{l}8 \text { varas de ceutí morado } \\
5 \text { varas de contray de Flandes }\end{array}$ \\
\hline Solicitador de la Cancillería & Jaime Climent & $\begin{array}{l}8 \text { varas de ceutí negro } \\
6 \text { varas de contray de Flandes }\end{array}$ \\
\hline $\begin{array}{l}\text { Provisor fiscal y patrimonial de } \\
\text { la Corte }\end{array}$ & Antonio Bonet & $\begin{array}{l}6 \text { varas de contray de Valencia } \\
2 \text { varas de terciopelo negro } \\
1 \text { chamelote negro }\end{array}$ \\
\hline \multirow[t]{5}{*}{ Escribanos de Mandamiento } & Antonio Salabert & $\begin{array}{l}6 \text { varas de ceutí negro } \\
5 \text { varas de contray de Flandes } \\
2 \text { varas de ceutí morado }\end{array}$ \\
\hline & Juan González & $\begin{array}{l}6 \text { varas de ceutí negro } \\
6 \text { varas de contray de Flandes } \\
2 \text { varas de ceutí morado }\end{array}$ \\
\hline & Juan Ruiz de Calcena & $\begin{array}{l}6 \text { varas de contray de Flandes } \\
6 \text { varas de terciopelo negro } \\
2 \text { varas de ceutí carmesí }\end{array}$ \\
\hline & Juan de Serralonga & $\begin{array}{l}8 \text { varas de ceutí morado } \\
5 \text { varas de trapo pardo de Venecia }\end{array}$ \\
\hline & Arnau Pérez & $\begin{array}{l}8 \text { varas de ceutí negro } \\
5 \text { varas de contray de Flandes }\end{array}$ \\
\hline \multirow[t]{3}{*}{ Ayudantes de la cancillería ${ }^{53}$} & Andrés de las Risas & \multirow{3}{*}{$\begin{array}{l}\text { A cada uno: } \\
5 \text { varas de trapo de Valencia pardo } \\
2 \text { varas y } 1 / 4 \text { de contray de Flandes } \\
2 \text { varas de ceutí negro de Valencia }\end{array}$} \\
\hline & Jaime Remiro & \\
\hline & Pedro de Aperet & \\
\hline \multirow[t]{2}{*}{ Hoste de correo } & Beltrán Bollón & $\begin{array}{l}7 \text { varas de trapo verde oscuro de } \\
\text { Valencia } \\
2 \text { varas de terciopelo negro }\end{array}$ \\
\hline & Su mujer & $\begin{array}{l}4 \text { varas de contray de Flandes } \\
4 \text { varas de Londres } \\
1 \text { pieza de chamelote }\end{array}$ \\
\hline Calentador de la cera & Juan de León & $\begin{array}{l}5 \text { varas de trapo de Valencia (pardo) } \\
2 \text { varas y } 1 / 4 \text { de contray de Flandes } \\
2 \text { varas de ceutí negro de Valencia }\end{array}$ \\
\hline \multirow[t]{2}{*}{ Sellador } & Francisco de Paz & \\
\hline & Su mujer (Beatriz González) & $\begin{array}{l}4 \text { varas de contray de Flandes } \\
4 \text { varas de Londres } \\
1 \text { chamelote }\end{array}$ \\
\hline Sellador & Guillem de Fet & $\begin{array}{l}6 \text { varas de ceutí negro } \\
5 \text { varas de contray de Flandes } \\
2 \text { varas de ceutí morado }\end{array}$ \\
\hline Capellán mayor & Mosén Alonso Cortés & $\begin{array}{l}8 \text { varas de contray de Flandes } \\
1 \text { chamelote negro }\end{array}$ \\
\hline
\end{tabular}

53 Se corresponden con los escribanos del registro de la cancillería. 
LAS LIBREAS EN EL SÉQUITO DE FERNANDO EL CATÓLICO: RELACIONES

\begin{tabular}{|c|c|c|}
\hline Cargo & Oficial & Librea \\
\hline \multirow[t]{2}{*}{ Capellanes } & Antonio de Castelrianes & $\begin{array}{l}10 \text { varas y } 1 / 2 \text { de contray de Valencia } \\
2 \text { varas de ceutí negro }\end{array}$ \\
\hline & Mosén Antonio Sánchez & $\begin{array}{l}7 \text { varas de contray } \\
2 \text { varas y } 2 / 3 \text { de chamelote } \\
2 \text { varas y } 1 / 3 \text { de Londres } \\
\end{array}$ \\
\hline Capellán y cantor & Mosén Pedro Díez Daux & 8 varas de contray de Flandes \\
\hline \multirow[t]{8}{*}{ Mozos de Capilla } & Francisco de Alfaro & \multirow{8}{*}{$\begin{array}{l}\text { A cada uno: } \\
7 \text { varas de Londres pardo y morado } \\
1 / 2 \text { vara de terciopelo negro } \\
1 \text { florín para un gipón }\end{array}$} \\
\hline & Juan Andía & \\
\hline & Juan Cortés & \\
\hline & Juan Fortuoso & \\
\hline & Martín de Alfaro & \\
\hline & Juan de Vega & \\
\hline & Martín Cortés & \\
\hline & Sebastián Palacios & \\
\hline \multirow[t]{4}{*}{ Reposteros de Capilla } & Álvaro de Maderuelo & \multirow{3}{*}{$\begin{array}{l}\text { A cada uno: } \\
7 \text { varas de Londres morado } \\
2 \text { varas de terciopelo negro }\end{array}$} \\
\hline & Juan de Briones & \\
\hline & Juan Navarro & \\
\hline & $\begin{array}{l}\text { A la mujer de Álvaro de } \\
\text { Maderuelo (Inés Âlvarez) }\end{array}$ & $\begin{array}{l}4 \text { varas de contray de Flandes } \\
4 \text { varas de Londres } \\
1 \text { chamelote negro }\end{array}$ \\
\hline \multirow[t]{3}{*}{ Reposteros de Capilla } & Juan D’Ávila & $\begin{array}{l}5 \text { varas de trapo pardo de Valencia } \\
2 \text { varas de grana de Londres } \\
2 \text { varas de terciopelo negro }\end{array}$ \\
\hline & García de Sesé & $\begin{array}{l}7 \text { varas de trapo verde oscuro de } \\
\text { Valencia } \\
2 \text { varas de terciopelo negro }\end{array}$ \\
\hline & Pedro Cortés & $\begin{array}{l}7 \text { varas de Londres morado y pardo } \\
2 \text { varas de terciopelo negro }\end{array}$ \\
\hline \multirow[t]{4}{*}{ Tesorero } & Gabriel Sánchez & $\begin{array}{l}14 \text { varas y } 1 / 2 \text { de terciopelo carmesí } \\
10 \text { varas de altibajo carmesí } \\
2 \text { varas de aceituní carmesí }\end{array}$ \\
\hline & Su mujer & $\begin{array}{l}12 \text { varas de altibajo carmesí } \\
8 \text { varas de terciopelo carmesí } \\
7 \text { varas de ceutí carmesí } \\
7 \text { varas de terciopelo morado carmesí }\end{array}$ \\
\hline & Su hijo Luis Sánchez & $\begin{array}{l}10 \text { varas de ceutí carmesí } \\
10 \text { varas de terciopelo morado carmesí } \\
5 \text { varas de altibajo carmesí }\end{array}$ \\
\hline & Su hijo Pedro Sánchez & $\begin{array}{l}9 \text { varas de ceutí carmesí } \\
9 \text { varas de terciopelo morado carmesí } \\
4 \text { varas y } 1 / 2 \text { de altibajo carmesí }\end{array}$ \\
\hline \multirow[t]{3}{*}{ Escribanos del tesorero } & Juan Tomás & \multirow{3}{*}{$\begin{array}{l}\text { A cada uno: } \\
7 \text { varas de contray de Flandes } \\
2 \text { varas de terciopelo negro }\end{array}$} \\
\hline & Juan de Ripoll & \\
\hline & Juan Granada & \\
\hline Escribano de Ración & Luis de Santángel & $\begin{array}{l}14 \text { varas de terciopelo carmesí } \\
10 \text { varas de altibajo carmesí } \\
2 \text { varas de aceituní carmesí }\end{array}$ \\
\hline
\end{tabular}


LAS LIBREAS EN EL SÉQUITO DE FERNANDO EL CATÓLICO: RELACIONES

Y REPRESENTACIONES DE LOS PODERES CORTESANOS

\begin{tabular}{|c|c|c|}
\hline Cargo & Oficial & Librea \\
\hline & Su mujer & $\begin{array}{l}12 \text { varas de altibajo carmesí } \\
8 \text { varas de terciopelo carmesí } \\
7 \text { varas de ceutí carmesí } \\
7 \text { varas de terciopelo morado carmesí }\end{array}$ \\
\hline & Su hijo Fernando de Santángel & $\begin{array}{l}12 \text { varas de ceutí carmesí } \\
12 \text { varas de terciopelo morado carmesí } \\
5 \text { varas de altibajo carmesí } \\
1 \text { vara y } 3 / 4 \text { de ceutí carmesí }\end{array}$ \\
\hline & Su hijo Jerónimo de Santángel & $\begin{array}{l}10 \text { varas de ceutí carmesí } \\
10 \text { varas de terciopelo morado carmesí } \\
4 \text { varas y } 6 / 12 \text { de altibajo carmesí }\end{array}$ \\
\hline \multirow[t]{2}{*}{ Escribano de la Tesorería } & Sancho Ruiz (II) & \multirow{2}{*}{$\begin{array}{l}12 \text { varas de aceituní morado } \\
9 \text { varas de terciopelo carmesí } \\
8 \text { varas de aceituní verde } \\
6 \text { varas de contray de Valencia } \\
\end{array}$} \\
\hline & Su mujer & \\
\hline \multirow{7}{*}{$\begin{array}{l}\text { Ayudante de la Tesorería y } \\
\text { Escribanía de Ración }\end{array}$} & Gaspar de Barrachina & \multirow{2}{*}{$\begin{array}{l}\text { A cada uno: } \\
6 \text { varas de contray de Flandes } \\
6 \text { varas de terciopelo negro } \\
2 \text { varas de ceutí carmesí }\end{array}$} \\
\hline & Simón Ruiz & \\
\hline & Bernardo García & \multirow{5}{*}{$\begin{array}{l}\text { A cada uno: } \\
8 \text { varas de ceutí negro y morado } \\
6 \text { varas de contray de Flandes }\end{array}$} \\
\hline & Lope López & \\
\hline & Juan Climent & \\
\hline & Juan Bautista de Granada & \\
\hline & Pedro Castellano & \\
\hline
\end{tabular}

Tabla 2. Oficios no contemplados en las Ordinacions, pero presentes en la lista de libreas.

\begin{tabular}{|c|c|c|}
\hline \multirow[t]{2}{*}{ Reyes de Armas } & Aragón & \multirow{2}{*}{$\begin{array}{l}\text { A cada uno: } \\
1 \text { sayo } \\
1 \text { gibón } \\
1 \text { tabardo }\end{array}$} \\
\hline & Castilla & \\
\hline \multirow[t]{9}{*}{ Maestresalas } & Diego de Rojas & $\begin{array}{l}17 \text { varas de terciopelo carmesí } \\
2 \text { varas de ceutí carmesí }\end{array}$ \\
\hline & Fernando de Toledo & \multirow{6}{*}{$\begin{array}{l}\text { A cada uno: } \\
17 \text { varas de terciopelo carmesí } \\
2 \text { varas de ceutí carmesí }\end{array}$} \\
\hline & Francisco de Rojas & \\
\hline & Íńigo López de Mendoza & \\
\hline & Juan Enríquez de Arellano & \\
\hline & Martín de Rojas & \\
\hline & Sancho de Rojas & \\
\hline & Gastón de Coutruix & \multirow{2}{*}{$\begin{array}{l}20 \text { varas de terciopelo carmesí } \\
20 \text { varas de terciopelo negro }\end{array}$} \\
\hline & Su mujer & \\
\hline \multirow[t]{4}{*}{ Ballesteros de Maza } & Alonso de Madrid & \multirow{4}{*}{$\begin{array}{l}\text { A cada uno: } \\
1 \text { gibón de terciopelo negro } \\
1 \text { capuzo de grana } \\
1 \text { sayo de tela de Londres morado }\end{array}$} \\
\hline & Juan Pérez & \\
\hline & Juan Muñoz & \\
\hline & Miguel de los Arcos & \\
\hline
\end{tabular}

54 Las telas mencionadas para estos oficiales son terciopelo verde (4 varas), pardo (13 varas) y grana de Valencia (13 varas y $2 / 12$ ), aunque no se especifica el uso en cada prenda. 
LAS LIBREAS EN EL SÉQUITO DE FERNANDO EL CATÓLICO: RELACIONES

\begin{tabular}{|c|c|c|}
\hline \multirow[t]{13}{*}{ Monteros de Espinosa } & García de Lerena & \multirow{13}{*}{$\begin{array}{l}\text { A cada uno: } \\
7 \text { varas de Londres morado y pardo } \\
1 / 2 \text { vara de terciopelo negro } \\
1 \text { florín }\end{array}$} \\
\hline & García de Lerena (mayor) & \\
\hline & García Sánchez & \\
\hline & Hernán Saravia & \\
\hline & Juan Negrete & \\
\hline & Juan de Macazo & \\
\hline & Juan Ortiz de Velasco & \\
\hline & Juan Zorrilla & \\
\hline & Pedro de Espinosa & \\
\hline & Pedro de Lerena & \\
\hline & Rodrigo Alonso & \\
\hline & Ruiz Gómez & \\
\hline & Sancho Hernández & \\
\hline \multirow[t]{20}{*}{ Mozos de Espuelas } & Alonso Gallego & \multirow{20}{*}{$\begin{array}{l}\text { A cada uno: } \\
1 \text { saya verde y roja } \\
1 \text { gibón de ceutí carmesí } \\
1 \text { capuzo hecho con tela de Londres } \\
1 \text { caperuza de terciopelo negro }\end{array}$} \\
\hline & Antón & \\
\hline & Cayado & \\
\hline & Escalona & \\
\hline & Diego Bote & \\
\hline & Gamboa & \\
\hline & García & \\
\hline & Juan Gaço & \\
\hline & Ochoa & \\
\hline & Vergara & \\
\hline & Salcedo & \\
\hline & Juan Palacios & \\
\hline & Juan Pérez & \\
\hline & Juancho & \\
\hline & Martín & \\
\hline & Mealles & \\
\hline & Perusque & \\
\hline & Torniente & \\
\hline & Rodrigo & \\
\hline & Zárate & \\
\hline $\begin{array}{l}\text { «Guardador» de la } \\
\text { Cámara }\end{array}$ & Juan de Alora & $\begin{array}{l}5 \text { varas de Londres morado } \\
2 \text { varas de grana rosada } \\
2 \text { varas de terciopelo negro }\end{array}$ \\
\hline Cronista & Fernando de Ribera & \multirow{2}{*}{$\begin{array}{l}\text { A cada uno: } \\
6 \text { varas de aceituní negro } \\
6 \text { varas de contray de Flandes } \\
2 \text { varas de ceutí carmesí }\end{array}$} \\
\hline Cronista & Gracia Dey & \\
\hline Guarnicionero & García de Arce & $\begin{array}{l}7 \text { varas de Londres pardo } \\
2 \text { varas de ceutí negro } \\
\end{array}$ \\
\hline Pajes & Alonso de la Caballería & $\begin{array}{l}5 \text { varas y } 2 / 3 \text { de terciopelo carmesí } \\
4 \text { varas y } 1 / 2 \text { de contray } \\
1 \text { vara y } 2 / 3 \text { de ceutí carmesí }\end{array}$ \\
\hline
\end{tabular}


LAS LIBREAS EN EL SÉQUITO DE FERNANDO EL CATÓLICO: RELACIONES

Y REPRESENTACIONES DE LOS PODERES CORTESANOS

\begin{tabular}{|c|c|c|}
\hline \multirow[t]{17}{*}{ Pajes } & Carlos de Chaus & $\begin{array}{l}6 \text { varas y } 1 / 2 \text { de terciopelo carmesí } \\
4 \text { varas y } 3 / 4 \text { de contray } \\
1 \text { vara y } 3 / 4 \text { de ceutí carmesí }\end{array}$ \\
\hline & Cristóbal Climent & $\begin{array}{l}6 \text { varas y } 1 / 2 \text { de terciopelo carmesí } \\
4 \text { varas y } 3 / 4 \text { de contray } \\
2 \text { varas de ceutí carmesí }\end{array}$ \\
\hline & Coscón & $\begin{array}{l}6 \text { varas y } 1 / 2 \text { de terciopelo carmesí } \\
4 \text { varas y } 3 / 4 \text { de contray } \\
2 \text { varas de ceutí carmesí }\end{array}$ \\
\hline & Melchor González & $\begin{array}{l}5 \text { varas de terciopelo carmesí } \\
3 \text { varas y } 1 / 3 \text { de contray de Valencia } \\
1 \text { vara y } 1 / 2 \text { de ceutí carmesí }\end{array}$ \\
\hline & Fabra & $\begin{array}{l}5 \text { varas de terciopelo carmesí } \\
3 \text { varas y } 3 / 4 \text { de contray } \\
1 \text { vara y } 1 / 3 \text { de ceutí carmesí }\end{array}$ \\
\hline & Fernando de Muir & $\begin{array}{l}2 \text { varas de ceutí carmesí } \\
6 \text { varas y } 1 / 2 \text { de terciopelo carmesí } \\
4 \text { varas y } 3 / 4 \text { de contray de Flandes }\end{array}$ \\
\hline & Francisco de Castilla & $\begin{array}{l}6 \text { varas y } 1 / 2 \text { de terciopelo carmesí } \\
4 \text { varas y } 3 / 4 \text { de contray } \\
2 \text { varas de ceutí carmesí }\end{array}$ \\
\hline & Francisco de Requesens & $\begin{array}{l}6 \text { varas y } 1 / 2 \text { de terciopelo carmesí } \\
4 \text { varas } 3 / 4 \text { de contray } \\
2 \text { varas de ceutí carmesí }\end{array}$ \\
\hline & Galcerán de Villaplana & $\begin{array}{l}6 \text { varas y } 1 / 2 \text { de terciopelo carmesí } \\
4 \text { varas y } 3 / 4 \text { de contray } \\
2 \text { varas ceutí carmesí }\end{array}$ \\
\hline & Gaspar de Ariño & $\begin{array}{l}6 \text { varas y } 1 / 2 \text { de terciopelo carmesí } \\
4 \text { varas y } 3 / 4 \text { de contray } \\
2 \text { varas ceutí carmesí }\end{array}$ \\
\hline & Gómez Carrillo & $\begin{array}{l}4 \text { varas de terciopelo carmesí } \\
3 \text { caras y } 1 / 2 \text { de contray } \\
1 \text { vara y } 1 / 3 \text { de ceutí carmesí }\end{array}$ \\
\hline & Jaime Díez & $\begin{array}{l}6 \text { varas y } 1 / 2 \text { de terciopelo carmesí } \\
4 \text { varas y } 3 / 4 \text { de contray } \\
2 \text { varas de ceutí carmesí }\end{array}$ \\
\hline & Jerónimo Agustín & $\begin{array}{l}1 \text { vara y } 3 / 4 \text { de ceutí carmesí } \\
6 \text { varas y } 1 / 4 \text { de terciopelo carmesí } \\
4 \text { varas y } 3 / 4 \text { de contray }\end{array}$ \\
\hline & Juan Agustín & $\begin{array}{l}6 \text { varas de terciopelo carmesí } \\
4 \text { varas y } 1 / 2 \text { de contray de Flandes } \\
1 \text { vara y } 3 / 4 \text { de ceutí carmesí }\end{array}$ \\
\hline & Juan Salazar & $\begin{array}{l}6 \text { varas y } 1 / 2 \text { de terciopelo carmesí } \\
4 \text { varas y } 3 / 4 \text { de contray } \\
2 \text { varas de ceutí carmesí }\end{array}$ \\
\hline & Juanot de Villanueva & $\begin{array}{l}5 \text { varas de terciopelo carmesí } \\
4 \text { varas de contray } \\
1 \text { vara y } 2 / 3 \text { de ceutí carmesí }\end{array}$ \\
\hline & Loaýsa & $\begin{array}{l}6 \text { varas y } 1 / 2 \text { de terciopelo carmesí } \\
4 \text { varas y } 3 / 4 \text { de contray } \\
2 \text { varas de ceutí carmesí }\end{array}$ \\
\hline
\end{tabular}


LAS LIBREAS EN EL SÉQUITO DE FERNANDO EL CATÓLICO: RELACIONES Y REPRESENTACIONES DE LOS PODERES CORTESANOS

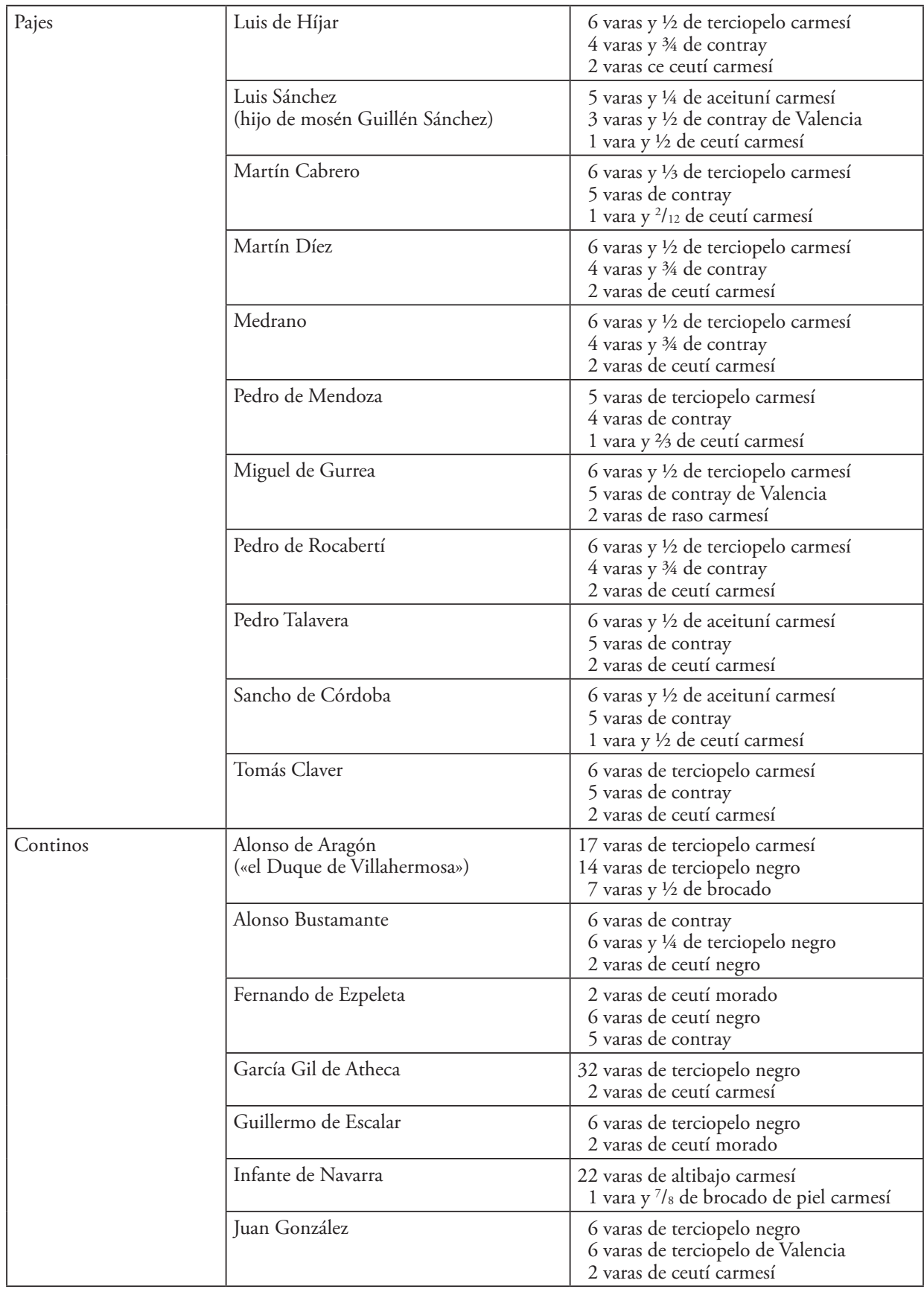


LAS LIBREAS EN EL SÉQUITO DE FERNANDO EL CATÓLICO: RELACIONES

Y REPRESENTACIONES DE LOS PODERES CORTESANOS

GERMÁN GAMERO IGEA

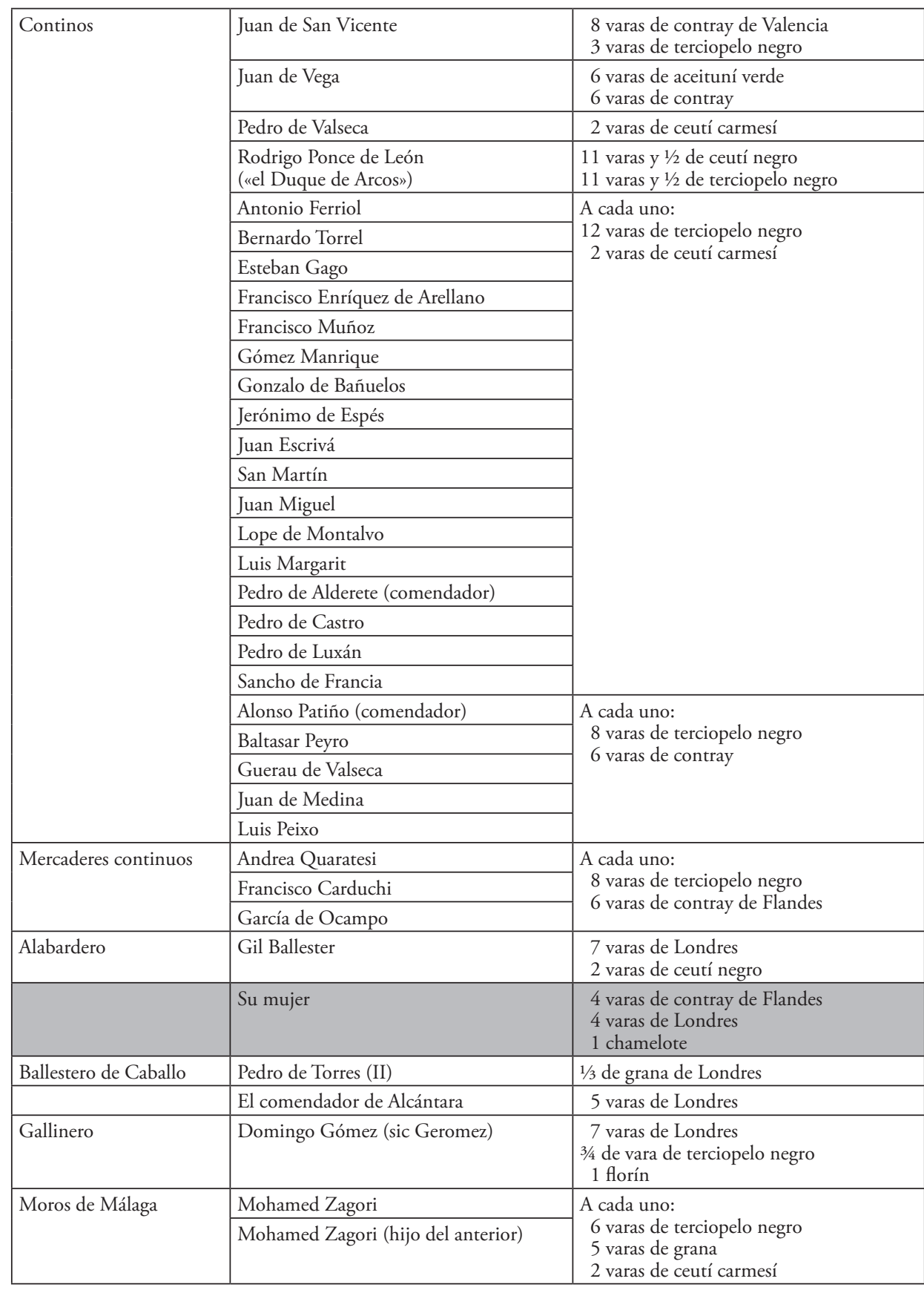


LAS LIBREAS EN EL SÉQUITO DE FERNANDO EL CATÓLICO: RELACIONES Y REPRESENTACIONES DE LOS PODERES CORTESANOS GERMÁN GAMERO IGEA

\begin{tabular}{|l|l|l|}
\hline Pelotero & Miguel & $\begin{array}{l}7 \text { varas de Londres } \\
1 / 2 \text { vara de terciopelo negro } \\
1 \text { florín }\end{array}$ \\
\hline Argentiers (Plateros) & Fernando Benet & $\begin{array}{l}7 \text { varas de contray de Flandes } \\
2 \text { varas de aceituní negro }\end{array}$ \\
\cline { 2 - 3 } & Jaime Aymerich & $\begin{array}{l}7 \text { varas y } 1 / 3 \text { de contray de Flandes } \\
2 \text { varas de aceituní negro }\end{array}$ \\
\cline { 2 - 3 } & Pedro Virgil & $\begin{array}{l}\text { 6 varas de terciopelo negro } \\
2 \text { varas de ceutí morado }\end{array}$ \\
\hline Fuster (carpintero) & Palacio (moro) & $\begin{array}{l}7 \text { varas de Londres } \\
2 \text { varas de ceutí morado }\end{array}$ \\
\hline
\end{tabular}

\section{ReFERENCIAS BIBLIOGRÁFICAS}

Alonso Cortés, Narciso. «Dos médicos de los Reyes Católicos». Hispania. Revista Española de Historia, 1951, vol. 45, pp. 607-657.

ANDrÉs DíAz, Rosana de. «Las entradas reales castellanas en los siglos XIV y xv, según las crónicas de la época». En la España Medieval, 1984, vol. 4, pp. 47-62.

Andrés DíAz, Rosana de. El último decenio del reinado de Isabel I a través de la tesorería de Alonso de Morales. Valladolid: Universidad de Valladolid, 2004.

Asch, Ronald G. y Birke, Adolf M. Princes, Patronage and the Nobility. Oxford: Oxford University Press, 1991.

Baltar Rodríguez, Juan Francisco. El protonotario de Aragón, 1472-1707: la Cancillería aragonesa en la Edad Moderna. Zaragoza: El Justicia de Aragón, 2001.

Bartholeyns, Gil. "Gouverner par le vêtement. Naissance d'une obsession politique». En GeNet, Jean-Philippe y Mineo, E. Igor (dirs.). Marquer la prééminence sociale. Paris-Roma: Publications de la Sorbonne-École Française de Rome, 2014, pp. 215-232.

Beauchamp, Alexandra. "La composition de la Casa i Cort du roi d'Aragon. Normes et pratiques au début du règne de Pierre le Cérémonieux». Erasmo. Revista de Historia Bajomedieval y Moderna, 2014, vol. 1, pp. 21-42.

Beauchamp, Alexandra. "Ordonnances et réformes de l'Hôtel Royal au début du règne de Pierre IV d'Aragón». Anuario de Estudios Medievales, 2009, vol. 39, n.o 2, pp. 555-573.

Belenguer Cebrià, Ernest. Fernando el Católico y la ciudad de Valencia. Valencia: Servicio de Publicaciones de la Universidad de Valencia, 2012.

Bernis, Carmen. Trajes y modas en la España de los Reyes Católicos. Madrid: Consejo Superior de Investigaciones Científicas, 1978-1979.

Bertelli, Sergio. "Il conceto di Corte». En Margolin, Jean-Claude; Bigalli, Davide; Tenenti, Alberto; Ingenio, Alfonso y Vassoli, Cesare (coords.). Ragione e civilitas. Figure del vivere associato nella cultura del' 500 europeo. Milano: Franco Angeli, 1986, p. 143.

Cañas Gálvez, Francisco de Paula. «García Fernández de Alcalá: notas biográficas y contextos institucionales de un secretario y agente fiscal del rey de Castilla (1440-1467)». En Borrero Fernández, Mercedes; Carrasco Pérez, Juan y Peinado Santaella, Rafael Gerardo (coords.). Agentes de los sistemas fiscales en Andalucía y los reinos hispánicos (siglos XIII-XVI): un modelo comparativo. Madrid: Instituto de Estudios Fiscales, 2014, pp. 67-84.

Cañas Gálvez, Francisco de Paula. "Juan de Mena, secretario de latín y cronista del rey: un letrado en la Cancillería Real al servicio de Juan II y Enrique IV». En Moya García, Cristina (coord.). Juan de Mena: de letrado a poeta. Woodbridge: Tamesis Books, 2015, pp. 11-22. 
LAS LIBREAS EN EL SÉQUITO DE FERNANDO EL CATÓLICO: RELACIONES

Y REPRESENTACIONES DE LOS PODERES CORTESANOS

GERMÁN GAMERO IGEA

Cañas Gálvez, Francisco de Paula. «La evolución política en Castilla durante el siglo xv: de Juan II a los Reyes Católicos. Perspectiva bibliográfica de la nueva historia política y sus aplicaciones metodológicas». e-Humanista, 2008, vol. 10, pp. 31-50.

Carrasco Manchado, Ana Isabel. Isabel I de Castilla y la sombra de la ilegitimidad. Propaganda y representación en el conflicto sucesorio (1474-1482). Madrid: Sílex, 2006.

Castillo Ocaña, Argente del. "Carmen, el vestido en la sociedad castellana bajomedieval». En García Wiedemann, Emilio J. y Montoya Ramírez, M. ${ }^{a}$ Isabel (eds.). Moda y sociedad. Estudios sobre educación, lenguaje e historia del vestido. Granada: Universidad de Granada, 1998, pp. 69-102.

Cauchies, Jean Marie. A la cour de Bourgogne. Le duc, son entoruage, son train. Turnhout: Brepols, 1998.

Chilà, Roxane. Une cour à l'épreuve de la conquête: la société curiale et Naples, capitale d'Alphonse le Magnanime (1416-1458). Tesis doctoral inédita defendida en la Université Paul ValéryMontpellier III en el año 2014 (disponible en https://tel.archives-ouvertes.fr/tel-01144965/).

Descalzo Lorenzo, Amalia. "Vestirse a la moda en la España Moderna». Vinculos de Historia, 2017, vol. 6, pp. 89-204.

Domínguez Casas, Rafael. Arte y etiqueta de los Reyes Católicos. Artistas, residencias, jardines y bosques. Madrid: Alpuerto, 1993.

Escudero, José Antonio. Los secretarios de Estado y del Despacho (1474-1724). Madrid: Instituto de Estudios Administrativos, 1976.

Ezquerra Revilla, Javier y Martínez Millán, José. «La integración de las élites sociales en las monarquías dinásticas: los continos». En Espacios de poder: cortes, ciudades y villas. Madrid: Jesús Bravo SL, 2002, pp. 339-380.

Fernández de Córdova Miralles, Álvaro. «Los símbolos del poder real». En Bartolomé, Alberto y Hernando, Carlos José. Los Reyes Católicos y Granada. Granada: Sociedad Estatal de Conmemoraciones Culturales, 2005.

Fernández de Córdova Miralles, Álvaro. La Corte de Isabel I. Ritos y ceremonias de una reina (1464-1504). Madrid: Dykinson, 2002.

Fernández de Oviedo, Alonso. Libro de la Cámara Real del príncipe don Juan, oficios de su casa y servicio ordinario (Santiago Fabregat Barrios, ed.). València: Universitat de València, 2006, pp. 111-114.

Gamero Igea, Germán. «El modelo administrativo de la Corte de Fernando el Católico. Cambios y permanencias en la gestión cortesana de la Corona de Aragón». e-Spania, 2015, vol. 20.

Gamero Igea, Germán. «Epílogo de un reinado y desmembramiento de una Corte: servidores de Juan II de Aragón a su muerte». Medievalismo, 2016, vol. 26, pp. 109-133.

Gamero Igea, Germán. «Los continos en el reinado de Fernando el Católico. Oficiales entre la corte y la ciudad». En Carvajal, David; Vitores, Imanol y Añíbarro, Javier (eds.). Poder, fisco y mercado en las ciudades de la Península Ibérica (siglos XIV-XVI). Valladolid: Castilla Ediciones, 2016, pp. 193-208.

Gamero IgEA, Germán. «Los lazos familiares en la articulación cortesana de Fernando el Católico». En García Hernández, Máximo (ed.). Familia, cultura material y formas de poder en la España Moderna. Madrid: FEHM, 2016, pp. 33-42.

Gamero Igea, Germán. «Ordenar la Corte y gobernar los territorios. Dinámicas y estructuras de poder en el entorno de Fernando el Católico». En Nieva, Guillermo; González, Rubén y Navarro, Andrea M. (coords.). El principe, la corte y sus reinos. Tucumán: Universidad Nacional de Tucumán, 2016, pp. 139-166.

García Marsilla, Juan Vicente. «La moda no es capricho. Mensajes y funciones del vestido en la Edad Media». Vinculos de Historia, 2017, vol. 6, pp. 71-88. 
García Vera, María José. «Los estudios sobre la corte y la "sociedad cortesana” a fines de la Edad Media. Un balance historiográfico». Medievalismo, 2000, vol. 10, pp. 207-267.

Gimeno, Francisco M.; Gozalbo, Daniel y Trenchs, Josep (eds.). Ordinacions de la Casa i Cort de Pere el Ceremoniós. València: Publicacions de la Universitat de València, 2009.

GonZÁlez Arce, José Damián. «Los colores de la corte del príncipe Juan (1478-1497), heredero de los Reyes Católicos. Aspectos políticos, estéticos y económicos». Espacio, Tiempo y Forma. Serie III. Historia Medieval, 2013, vol. 26, pp. 185-208.

GonZÁlez ArCe, José Damián. Apariencia y poder: la legislación suntuaria castellana en los siglos XIII y XV. Jaén: Universidad de Jaén, 1998.

GonZÁlez Arce, José Damián. La casa y corte del príncipe don Juan (1478-1497). Sevilla: Sociedad Española de Estudios Medievales, 2016.

González Marrero, María del Cristo. «Un vestido para cada ocasión: la indumentaria de la realeza bajomedieval como instrumento para la afirmación, la imitación y el boato. El ejemplo de Isabel I de Castilla». Cuadernos del Cemyr, 2014, vol. 22, pp. 155-194.

González Marrero, María del Cristo. La casa de Isabel la Católica. Espacios domésticos y vida cotidiana. Ávila: Institución Gran Duque de Alba, 2005.

Gonzalez, Élisabeth. Un Prince en son Hôtel. Les serviteurs des ducs d'Orléans au XV siècle. Paris: Publications de la Sorbonne, 2004.

Gual Camarena, Miguel. «Servidores del infante don Fernando (1458-1462)». En Estudios de Edad Media de la Corona de Aragón. Zaragoza: Consejo Superior de Investigaciones Científicas, 1956, pp. 267-280.

Huizinga, Johan. El otoño de la Edad Media. Madrid: Alianza Editorial, 2005.

Jolivet, Sophie. «Le phénomène de mode à la cour de Bourgogne sous Philippe le Bon: l'exemple des robes de 1430 à 1442». Revue du Nord, 2006, vol. 365, n.o 2, pp. 331-345.

Knighton, Tess. Música y músicos en la corte de Fernando el Católico. Zaragoza: Institución Fernando el Católico, 2001.

Ladero Quesada, Miguel Ángel. "Actividades de Luis de Santángel en la corte de Castilla». Historia. Instituciones. Documentos, 1992, vol. 19, pp. 231-252.

Ladero Quesada, Miguel Ángel. «La casa real en la Baja Edad Media». Historia. Instituciones. Documentos, 1998, vol. 25, pp. 327-350.

Ladero Quesada, Miguel Ángel. Las fiestas en la Europa medieval. Madrid: Dykinson, 2015.

Martínez López, Francisco. La Casa del príncipe de Asturias (D. Juan, heredero de los Reyes Católicos). Madrid: Dykinson, 2007.

Martínez Martínez, María. «La creación de una moda propia en la España de los Reyes Católicos». Aragón en la Edad Media, 2006, vol. 19, pp. 343-380.

Martínez Millán, José. «La sustitución del "sistema cortesano" por el paradigma del "Estado nacional” en las investigaciones históricas». Libros de la Corte, 2009, vol. 1, pp. 4-17.

Martínez Millán, José (coord.). La Corte de Carlos V. Madrid: Sociedad Estatal para la Conmemoración de los Centenarios de Felipe II y Carlos V, 2000.

Muñoz Gómez, Víctor. «Una aproximación a la presencia castellana en el gobierno de la Corona de Aragón durante el reinado de Fernando I». En Falcón, Isabel (coord.). XIX Congreso de Historia de la Corona de Aragón. Zaragoza: Obra Social de Ibercaja, 2013, pp. 548-559.

Narbona Cárceles, María. La corte de Carlos III el Noble, rey de Navarra: espacio doméstico y escenario del poder, 1376-1415. Pamplona: Eunsa, 2006.

Nogales Rincón, David. «El color negro: luto y magnificencia en la Corona de Castilla (siglos XIII-XV)». Medievalismo, 2016, vol. 26, pp. 221-245.

Osés Urricelqui, Mercedes. Poder, simbología y representación en la Baja Edad Media. El ajuar en la corte de Carlos III de Navarra (1387-1425). Tesis doctoral inédita defendida en la 
LAS LIBREAS EN EL SÉQUITO DE FERNANDO EL CATÓLICO: RELACIONES

Y REPRESENTACIONES DE LOS PODERES CORTESANOS

GERMÁN GAMERO IGEA

Universidad Pública de Navarra en 2015 (disponible en https://academica-e.unavarra.es/ xmlui/handle/2454/18004).

Palacios Martín, Bonifacio. «Sobre la redacción y difusión de las Ordinacions de Pedro IV de Aragón y sus primeros códices». Anuario de Estudios Medievales, 1995, vol. 25, n. ${ }^{\circ}$ 2, pp. 659-682.

Paravicini Bagliani, Agostino. La chasse au Moyen Âge: société, traités, symboles. Firenze: SISMEL-Edizioni del Galluzzo, 2000.

Pascual Molina, Jesús Félix. «Magnificencia y poder en los festejos de la primera mitad del siglo xvi». En Rodríguez Moya, Inmaculada y Mínguez Cornelles, Víctor. Visiones de un imperio en fiesta. Madrid: Fundación Carlos de Amberes, 2016, pp. 121-144.

Pastoureau, Michel. «Nacimiento de un mundo en blanco y negro: la Iglesia y el color, de los orígenes a la Reforma». En Ídem. Una Historia simbólica de la Edad Media. Buenos Aires: Katz, 2006, pp. 147-234.

Pastoureau, Michel. Diccionario de los colores. Barcelona: Paidós Ibérica, 2009.

Paulicelli, Eugenia. Writing Fashion in Early Modern Italy. London: Routledge, 2016.

Pulgar, Hernando del. Crónica de los señores Reyes Católicos Don Fernando y Doña Isabel de Castilla y de Aragón. Valladolid: Junta de Castilla y León, 2011 [reimpresión de la edición de Valencia, Imprenta de Benito de Monfor, 1780].

Quintanilla Raso, M. ${ }^{a}$ Concepción. «La nobleza». En Nieto Soria, José Manuel. Orígenes de la monarquía hispánica: propaganda y legitimación ca.1400-1520. Madrid: Dykinson, 1999, pp. 63-104.

Quondam, Amadeo. Tutti i colori del nero. Moda e cultura nell'Italia del Cinquecento. Roma: Colla Editore, 2010.

Raufast CHico, Miguel. «E vingueren los officis e confraries ab llurs entremeses e balls: una aproximación al estamento artesanal en la Barcelona bajomedieval, a partir del estudio de las ceremonias de entrada real». Anuario de Estudios Medievales, 2006, vol. 36, n. ${ }^{\circ}$ 2, pp. 651-686.

Rivero Rodríguez, Manuel. «Court Studies in the Spanish World». En Fantoni, Marcello (ed.). The court in Europe. Roma: Bulzoni, 2012, pp. 123-147.

Sainz Serrano, Jorge. "Acompagner et servir le prince. Structure et fonctionament de la Maison royale d'Alphonse V D’Aragon». En Beauchamp, Alexandra (coord.). Les entourages princiers à la fin du Moyen Âge. Madrid: Casa de Velázquez, 2013, pp. 131-150.

SÁnchez Ortiz, Alicia. «El color: símbolo de poder y orden social. Apuntes para una historia de las apariencias en Europa». Espacio, Tiempo y Forma. Serie IV. Historia Moderna, 1999, vol. 12, pp. 321-354.

Sarasa SÁnchez, Esteban (coord.). Fernando II de Aragón, el Rey Católico. Zaragoza: Institución Fernando el Católico, 1996.

Sesma Muñoz, Ángel. Fernando de Aragón: Hispanorum Rex. Zaragoza: Gobierno de Aragón, 1992.

Sevillano Colom, Francisco. «La Cancillería de Fernando el Católico». En Actas del V Congreso de Historia de la Corona de Aragón. Zaragoza: Institución Fernando el Católico, 1955, pp. 217-353.

Starkey, David. The English Court: from the War of the Roses to the Civil War. London-New York: Longman, 1987.

Stegmann, André. «La Corte. Saggio di definizione teorica». En Romani, Marzio A. (ed.). Le corti farnesiane di Parma e Piacenza (1545-1622). Roma: Biblioteca del Cinquecento, 1978, Vol. I, pp. XXI-XXVI.

SuÁrez Fernández, Luis. Fernando el Católico. Barcelona: Ariel, 2004. 
SuÁREZ FernÁndez, Luis. Nobleza y monarquía: entendimiento y rivalidad. El proceso de construcción de la Corona española. Madrid: La Esfera, 2003.

Torre, Antonio de la y Torre, Engracia Alsina de la. Cuentas de Gonzalo de Baeza tesorero de Isabel la Católica. Madrid: Consejo Superior de Investigaciones Científicas, 1955-1956.

Valdeón Baruque, Julio. «La corte en Castilla en la época trastámara». Aragón en la Edad Media, 1999, vol. 14-15, pp. 1597-1608.

VÁzquez Gestal, Pablo. El Espacio del poder. La corte en la historiografía modernista española y europea. Valladolid: Universidad de Valladolid, 2005.

Vicens Vives, Jaume. Ferran II i la ciutat de Barcelona, 1479-1516. Barcelona: Universidad de Barcelona, 1936.

Vicens Vives, Jaume. Historia crítica de la vida y reinado de Fernando II de Aragón. Zaragoza: Institución Fernando el Católico, 2007 [Primera versión de 1962].

Zalama Rodríguez, Miguel Ángel. «Oro, perlas, brocados... La ostentación en el vestir en la corte de los Reyes Católicos». Revista de Estudios Colombinos, 2012, vol. 8, pp. 13-22. 